\title{
Cross-presentation and genome-wide screening reveal candidate $T$ cells antigens for a herpes simplex virus type 1 vaccine
}

Lichen Jing, ${ }^{1}$ Jürgen Haas, ${ }^{2,3}$ Tiana M. Chong, ${ }^{4}$ Joseph J. Bruckner, ${ }^{1}$ Greg C. Dann, ${ }^{1}$ Lichun Dong, ${ }^{1}$ Joshua O. Marshak, ${ }^{1}$ Christopher L. McClurkan, ${ }^{4}$ Tori N. Yamamoto, ${ }^{5}$ Susanne M. Bailer, ${ }^{2}$ Kerry J. Laing, ${ }^{1}$ Anna Wald,, ${ }^{1,6,7}$ Georges M.G.M. Verjans, ${ }^{8}$ and David M. Koelle, $1,4,6,10$

\begin{abstract}
${ }^{1}$ Department of Medicine, University of Washington, Seattle, Washington, USA. ${ }^{2}$ Max von Pettenkofer-Institut, Munich, Germany. ${ }^{3}$ Division of Pathway Medicine, University of Edinburgh, Edinburgh, United Kingdom. ${ }^{4}$ Department of Laboratory Medicine, University of Washington, Seattle, Washington, USA. ${ }^{5}$ Clinical Research Division and 6 Vaccine and Infectious Diseases Division, Fred Hutchinson Cancer Research Center, Seattle, Washington, USA. ${ }^{7 D e p a r t m e n t}$ of Epidemiology, University of Washington, Seattle, Washington, USA. ${ }^{8}$ Department of Virology, Erasmus Medical Center, Rotterdam, The Netherlands. ${ }^{9}$ Department of Global Health, University of Washington, Seattle, Washington, USA. ${ }^{10}$ Benaroya Research Institute, Seattle, Washington, USA.
\end{abstract}

\begin{abstract}
Herpes simplex virus type 1 (HSV-1) not only causes painful recurrent oral-labial infections, it can also cause permanent brain damage and blindness. There is currently no HSV-1 vaccine. An effective vaccine must stimulate coordinated $\mathrm{T}$ cell responses, but the large size of the genome and the low frequency of HSV-1-specific $T$ cells have hampered the search for the most effective $T$ cell antigens for inclusion in a candidate vaccine. We have now developed what we believe to be novel methods to efficiently generate a genome-wide map of the responsiveness of HSV-1-specific T cells, and demonstrate the applicability of these methods to a second complex microbe, vaccinia virus. We used cross-presentation and CD137 activation-based FACS to enrich for polyclonal $\mathrm{CD8}^{+} \mathrm{T}$ effector $\mathrm{T}$ cells. The HSV-1 proteome was prepared in a flexible format for analyzing both $\mathrm{CD8}^{+}$and $\mathrm{CD}^{+} \mathrm{T}$ cells from study participants. Scans with participant-specific panels of artificial APCs identified an oligospecific response in each individual. Parallel CD137-based $\mathrm{CD}^{+} \mathrm{T}$ cell research showed discrete oligospecific recognition of HSV-1 antigens. Unexpectedly, the two HSV-1 proteins not previously considered as vaccine candidates elicited both $\mathrm{CD8}^{+}$and $\mathrm{CD}^{+} \mathrm{T}$ cell responses in most $\mathrm{HSV}$-1-infected individuals. In this era of microbial genomics, our methods - also demonstrated in principle for vaccinia virus for both $\mathrm{CDB}^{+}$ and $\mathrm{CD}^{+} \mathrm{T}$ cells - should be broadly applicable to the selection of $\mathrm{T}$ cell antigens for inclusion in candidate vaccines for many pathogens.
\end{abstract}

\section{Introduction}

Herpes simplex virus type 1 (HSV-1) infects $60 \%$ of the US population and has a significant cumulative health care burden in addition to causing painful recurrent oral-labial infections. For example, brain and eye infections can cause permanent damage or blindness (1). HSV-1 also causes approximately $50 \%$ of clinical first-episode genital herpes in the United States. Vaccines for HSV that have been tested thus far have failed in clinical trials, including a recent phase III trial of an adjuvanted glycoprotein D (gD2) product (2). This vaccine elicits antibody and $\mathrm{CD} 4^{+} \mathrm{T}$ cell responses but fails to induce CD8 responses. Newer platforms can elicit CD8 ${ }^{+}$ and $\mathrm{CD} 4^{+}$cells, but they require rationally selected $\mathrm{T}$ cell antigens. We therefore developed methods to permit measurement of both CD8 and CD4 responses to the complete HSV-1 proteome to begin rational prioritization of next-generation vaccine candidates.

Several recent observations support the concept that an effective $\mathrm{HSV}$ vaccine will need to induce coordinated $\mathrm{CD} 8^{+}$and $\mathrm{CD} 4^{+}$ $\mathrm{T}$ cell responses. HSV-1-specific $\mathrm{CD}^{+} \mathrm{T}$ cells localize to the site of HSV-1 infection in human and murine trigeminal ganglia (TG) (3-5), and both HSV-specific $\mathrm{CD}^{+}$and $\mathrm{CD}^{+} \mathrm{T}$ cells localize to acute and healed sites of skin infection in mice and humans, sug-

Conflict of interest: David M. Koelle has received consulting fees from Immune Design Corp. and research support from Coridon Pty Ltd. and Vical Inc. Anna Wald has received research funding and consulting fees from AiCuris.

Citation for this article: J Clin Invest. 2012;122(2):654-673. doi:10.1172/JCI60556. gesting that optimally programmed memory cells could monitor for infection or reactivation (6-8). In animals, HSV ganglionic load correlates with reactivation frequency, so pre-equipping an individual with $\mathrm{HSV}$-specific $\mathrm{CD}^{+} \mathrm{T}$ cells could reduce seeding of the ganglia, even if a primary infection occurs in recipients of a non-sterilizing vaccine, and ameliorate the chronic disease $(9,10)$. Strong $\mathrm{CD}^{+}$responses can be protective in HSV infection-specific mouse models (11). In murine protection models based on attenuated live virus or DNA vaccines, protection is more typically CD4 dependent, and in humans, HSV disease worsens with CD4 depletion in untreated human immunodeficiency virus type 1 (HIV-1) infection $(12,13)$.

The breadth and specificity of HSV-1-specific T cells in humans is largely unknown. The virus has a large, $152-\mathrm{kb}$ genome encoding about 77 polypeptides $(14,15)$. BenMohamed et al. demonstrated A*0201-restricted responses to HSV-1 glycoprotein D $(16,17)$. A limited number of CD8 epitopes discovered in the context of HSV-2 research are sequence identical and thus cross-reactive with HSV-1. In HSV-1-infected human eyes, we have demonstrated CD4 reactivity with proteins in the viral tegument encoded by genes UL21, UL46, UL47, and UL49 (18-23). Envelope glycoproteins gD1 and gB1 are also known CD4 antigens (24).

The rules governing CD8 specificity are an important issue for HSV vaccine design. HSV genes are expressed in sequential, coordinated kinetic waves during the viral replication cycle, and a subset of proteins are present in virions and injected into cells upon 


\section{Table 1}

Participants studied in this report

\begin{tabular}{|c|c|c|c|c|c|c|c|c|c|c|}
\hline ID & Age & Sex & HSV-1 ${ }^{A}$ & HSV-2A & HLA-AB & HLA-B & HLA-C & HLA-DRB1 & HLA-DRB3,4,5 & HLA-DQB1 \\
\hline 1 & 29 & M & pos & neg & ${ }^{*} 01 \mathrm{xx},{ }^{\star} 0201$ & *5101, *5801 & ${ }^{\star} 0202,{ }^{\star} 07: 01: 01 \mathrm{G}$ & *0701 & & *0202 \\
\hline 2 & 42 & $\mathrm{~F}$ & pos & pos & ${ }^{\star} 01 x x,{ }^{\star} 26 x x$ & ${ }^{\star} 07 x x,{ }^{\star} 08 x x$ & *0702/0750, *07:01:01G & *1501, *0301 & $3^{\star} 0301,5^{\star} 0101$ & ${ }^{*} 0602,{ }^{*} 0201$ \\
\hline 3 & 24 & $\mathrm{~F}$ & pos & pos & *2902, *6801 & * $1516,{ }^{*} 4402$ & ${ }^{\star} 0704 / 0711,{ }^{*} 1402$ & ${ }^{*} 0401$ *1101 & 3 pos, 4 pos & *0301 \\
\hline 4 & 42 & $\mathrm{~F}$ & pos & pos & *2901, *6801 & ${ }^{*} 3503,{ }^{*} 4402$ & ${ }^{*} 04: 01: 01 \mathrm{G} 1,{ }^{*} 0704 / 0711$ & ${ }^{\star} 0401,{ }^{\star} 1104$ & 3 pos, 4 pos & ${ }^{\star} 0301,{ }^{*} 0302$ \\
\hline 5 & 44 & M & pos & pos & ${ }^{\star} 01 x x,{ }^{*} 0201$ & ${ }^{\star} 08 x x,{ }^{\star} 51 x x$ & ${ }^{\star} 0102,{ }^{*} 07: 01: 01 \mathrm{G}$ & *0101, *0301 & 3 pos & ${ }^{\star} 0201,{ }^{*} 0501$ \\
\hline 6 & 36 & M & pos & pos & ${ }^{*} 0201,{ }^{\star} 24 x x$ & $\begin{array}{c}\text { *0305, } \\
\text { *3503/3570 }\end{array}$ & ${ }^{*} 04: 01: 01 \mathrm{G}$ & ${ }^{*} 1104,{ }^{*} 1401$ & 3 pos & ${ }^{\star} 0301,{ }^{*} 0503$ \\
\hline 7 & 40 & M & pos & pos & ${ }^{\star} 0220,{ }^{\star} 0224$ & ${ }^{*} 4402,{ }^{*} 0702$ & *0501/0503, *0702/0750 & *0101, *0701 & 4 pos & ${ }^{\star} 0201,{ }^{*} 0501$ \\
\hline 8 & 29 & $\mathrm{~F}$ & pos & neg & Not done & & & & & \\
\hline 9 & 29 & $\mathrm{~F}$ & pos & neg & Not done & & & & & \\
\hline 10 & 20 & $\mathrm{~F}$ & pos & neg & Not done & & & & & \\
\hline 11 & 20 & $\mathrm{~F}$ & pos & neg & Not done & & & & & \\
\hline 12 & 55 & M & neg & neg & ${ }^{\star} 02 x x$ & ${ }^{\star} 51 x x,{ }^{\star} 60 x x$ & ${ }^{\star} 01 x x,{ }^{\star} 03 x x$ & *0101, *1501 & 5 pos & ${ }^{\star} 0501,{ }^{*} 0602$ \\
\hline 13 & 45 & $\mathrm{~F}$ & neg & neg & Not done & & & & & \\
\hline 14 & 50 & M & neg & neg & $\begin{array}{c}\text { *02xx, } \\
{ }^{*} 6601 / 6604\end{array}$ & ${ }^{\star} 38 x x,{ }^{\star} 39 x x$ & * $12 x x$ & ${ }^{\star} 16 x x,{ }^{\star} 11 x x$ & 3 pos, 5 pos & ${ }^{\star} 03 x x,{ }^{\star} 05 x x$ \\
\hline
\end{tabular}

AAt time of phlebotomy. ${ }^{B} H L A$ nomenclature at A and B according to the older system (92); the newer system is used for HLA-C (73) (see Methods). The presence or absence of a functional allele at the HLA-DRB3, 4 , and 5 loci is indicated for some individuals, and the alleles are identified for others.

viral entry. Some replication-incompetent whole HSV vaccines are blocked at the DNA replication step, such that true late proteins, which are only made after DNA replication, are not expressed (25). Other strains have a later replication block, with true late proteins being synthesized in the cytoplasm of infected cells (26). This property is shared by attenuated but replication-competent candidates (27). One of our goals was therefore to determine whether the CD8 response is weighted toward any specific kinetic or structural subset of HSV-1 proteins.

HSV immune evasion and the low abundance of HSV-specific $\mathrm{CD}^{+}$cells in human blood have made the study of HSV-specific $T$ cell responses difficult. Inhibition of transporter associated with antigen presentation (TAP), downregulation of HLA class I $(28,29)$, decreased DC co-stimulation (30), and disruption of TCR signaling $(31,32)$ mediated by various HSV genes all likely contribute to difficulties with direct presentation in in vitro settings. In contrast, murine HSV data show that both the priming of naive CD8 responses and the recall of memory $\mathrm{CD}^{+}$cells use cross- rather than direct priming and presentation (33-38). We have previously shown that human monocyte-derived DCs (moDCs) can crosspresent HSV-2 to memory HSV-2-specific CD8s (39). In this report, we harnessed cross-presentation to stimulate HSV-1-specific CD8 ${ }^{+}$ $\mathrm{T}$ cells, while $\mathrm{CD} 4^{+}$memory cells were reactivated with whole killed antigen. CD137 was then used to radically enrich HSV-1-specific $\mathrm{T}$ cells. CD137 is a tumor necrosis factor receptor family protein that identifies recently activated $\mathrm{CD}^{+}$and $\mathrm{CD} 8^{+} \mathrm{T}$ cells (40-42). A near complete collection of HSV-1 molecular clones was deployed in specific CD8 and CD4 formats to perform genome-wide scans of these polyclonal virus-specific $T$ cells. Our data identified the proteins expressed by HSV-1 genes UL39 and UL46, previously not known to be $\mathrm{CD}^{+} \mathrm{T}$ cell antigens, as rational vaccine candidates for the elicitation of coordinated CD8 and CD4 responses. In contrast, $\mathrm{gD} 1$, the homolog of gD2, was a poor CD8 antigen.

To test the broad applicability of our methods, we evaluated vaccinia virus, a microbe with more than 200 genes. We studied whether moDC cross-presentation and CD137-based methods using whole virus would enrich vaccinia-reactive $\mathrm{CD}^{+}$and $\mathrm{CD}^{+}$
T cells. The affirmative results suggest that a modular approach to T cell antigen discovery and prioritization, modified on a case-bycase basis to reflect the biology of specific microbes, should be laterally transferable to challenging pathogens with large genomes.

\section{Results}

HSV-1-specific CD8 ${ }^{+}$T cells can be detected and enriched by cross-presentation. We studied $7 \mathrm{HSV}-1$-seropositive individuals (Table 1), in whom we measured HSV-1-specific T cell responses in fine detail. In each case, exposure of $\mathrm{CD}^{+}$cells from PBMCs to autologous, HSV-1 antigen-loaded moDCs for 20 hours resulted in detectable $\mathrm{CD} 137$ responses among live $\mathrm{CD} 3^{+} \mathrm{CD} 8{ }^{+}$cells (representative participant, Figure 1A). We observed that specific expression of CD137 was usually somewhat higher than for IFN- $\gamma$ (Table 2). Among 3 individuals seronegative for HSV-1 and HSV-2 (individuals $12-14$, Table 1 ), two had very low CD137 and cytokine CD8 responses, while participant 13 had detectable responses in both assays (Table 2).

An advantage of using CD137 to detect HSV-1-reactive CD8 ${ }^{+}$ cells is the ability to sort and expand these cells for downstream testing. Sorted, polyclonal $\mathrm{CD} 3{ }^{+} \mathrm{CD} 8{ }^{+} \mathrm{CD} 137$ hi cells and control $\mathrm{CD}^{+} \mathrm{CD} 8^{+} \mathrm{CD} 137^{\mathrm{lo}}$ cells were expanded with a nonspecific mitogen. Resultant bulk populations were tested using autologous APCs infected by HSV-1. Significant proportions of the sorted, expanded CD137 hi cells selectively recognized the infected APCs (representative data for participant 1 after 2 cell expansions in Figure 1B; all individuals in Table 3), while the CD137lo cells were nonreactive. Cytotoxicity was used to assess the antiviral effector function of the sorted, expanded cells. Brisk, self-restricted killing was noted for most participants (Table 3).

Detection and HLA restriction of HSV-1 antigen-specific $\mathrm{CD}^{+} \mathrm{T}$ cells. We cryopreserved more than $10^{8}$ responder cells/individual and interrogated their responses with panels of artificial APCs (aAPCs), expressing one of the participant's HLA-A, -B, or -C molecules, and specific fragments of HSV-1 genetic material. Full-length genes or fragments, together covering a total of 74 HSV-1 ORFs, were cloned into a custom vector suitable for expression in aAPCs. 
A

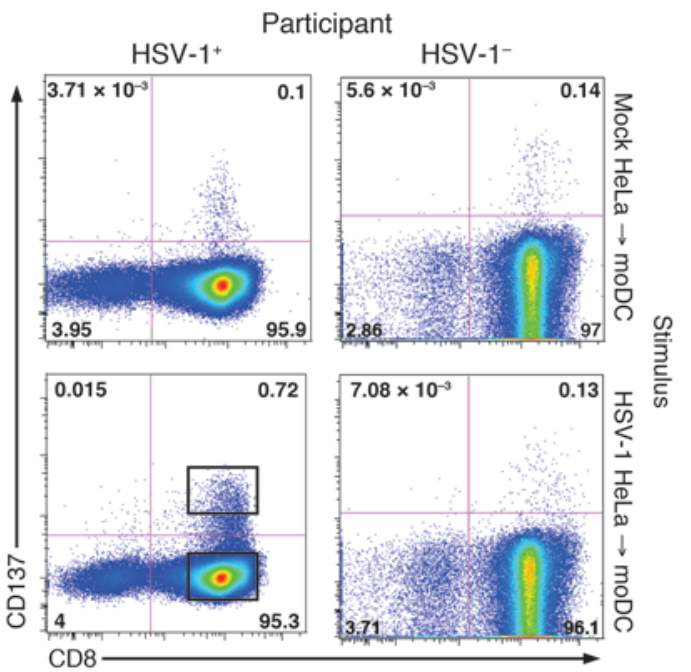

B

Gating
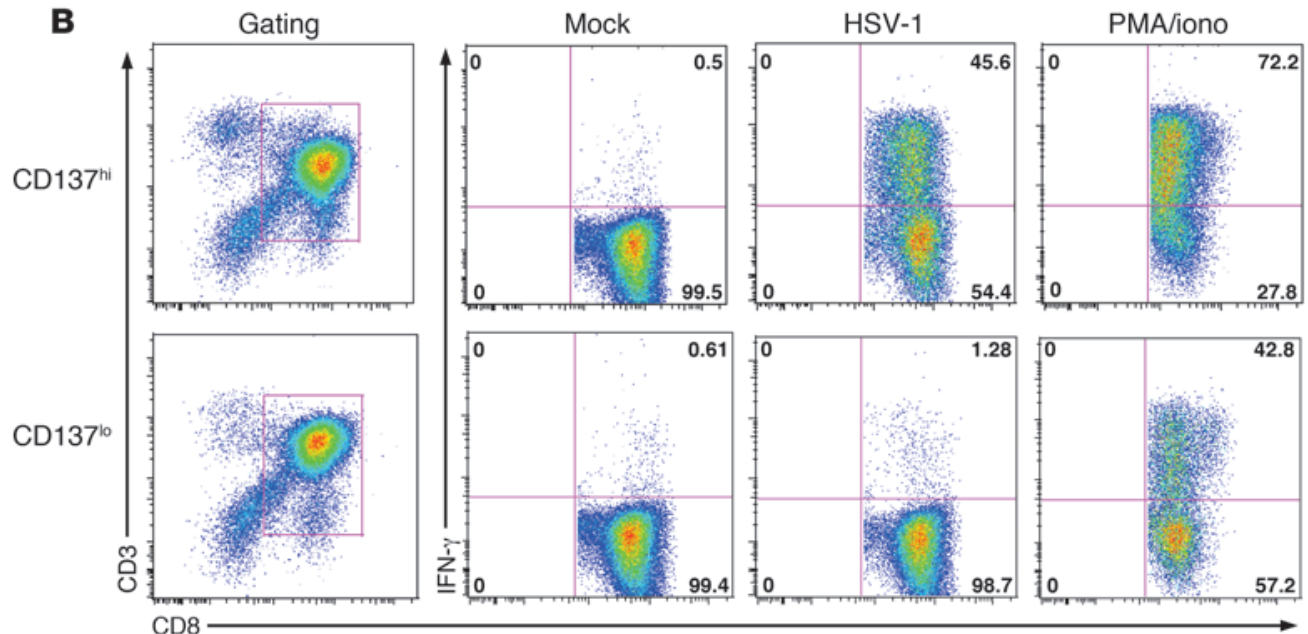

\section{Figure 1}

Use of CD137 to detect and enrich HSV-1-specific CD8 ${ }^{+} \mathrm{T}$ cells from blood. (A) Gated live, CD3+ lymphocyte forward/side scatter window cells analyzed for CD8 and CD137 after admixture of selected $\mathrm{CD} 8^{+}$cells with autologous moDCs loaded with mock- or HSV-1-infected HeLa cell debris (see Methods). Numbers are percentages of cells in indicated quadrants. Data for HSV-1-infected participant 1 and HSV-uninfected participant 12 are shown. Small boxes indicate approximate gates for FACS. (B) Reactivity of participant 1 polyclonal expanded responder cell line derived from $\mathrm{CD}^{+}{ }^{+} \mathrm{CD} 8^{+}{ }^{+} \mathrm{CD} 137^{\mathrm{hi}}$ or CD137/o cells after exposure to mockor HSV-1-infected autologous B-LCLs or control stimuli for 18 hours. Responder cells were initially gated using dump-gating of CFSE-labeled APCs (data not shown) and for CD3 and CD8 (left), and analyzed for intracellular IFN- $\gamma$. Numbers are percentages of cells in indicated quadrants. iono, ionomycin.
Transfection efficiency for HLA class I was typically 5\%-20\% at 48 hours (data not shown). Transfection efficiencies for the HSV-1 constructs were typically at least 10\% (Supplemental Figure 1; supplemental material available online with this article; doi:10.1172/ JCI60556DS1) as monitored with EGFP.

We completed CD8 ORFeome scans for every HLA-A, -B, and -C in 7 HSV-1-infected individuals (Table 1 ). $\mathrm{T}$ cell activation was monitored by IFN- $\gamma$ secretion after addition of polyclonal CD8 responders to the co-transfected aAPCs. Due to near-homozygosity in one participant per locus, some participants had one scan at HLA-A, -B, or -C. We used 21 distinct HLA class I cDNA molecules in all. The most frequently studied alleles were $A^{*} 0201$ ( 4 individuals) and $A * 0101, B * 4402$, and $\mathrm{Cw} 0701$ (3 individuals each).

We observed discrete IFN- $\gamma$ responses with very low backgrounds. A representative set of genome-wide screens for participant 1 (Figures 2, 3, and4) showed that each HLA allele had discrete CD8 reactivities. For example, genes UL39 and UL48 had strong reactivity restricted by HLA-A*0101, confirmed with synthetic peptides including two distinct epitopes in the UL48-endoded protein (Figure 5). Overall, there were 122 reactive combinations of HLA class I molecules and HSV-1 ORFs (Figure 6). The number of CD8 ORF-level hits per person ranged from 10 to 27 , with a median of 17 and mean \pm SD of $17 \pm 7$. Among these CD8 ORF-level hits, HLA-A was the most frequently used locus and HLA-C the least, with a mean \pm SD of $10 \pm 4.0,6.6 \pm 4.0$, and $1.3 \pm 1.7$ CD 8 ORF-level hits at the A, B, and C loci, respectively. All 6 HLA-A alleles and 6 of 7 HLA-B alleles had one or more responses, while 3 of the 8 HLA-C alleles $(0102,0402$, and 0704$)$ did not. Overall, 28 of the 39 (72\%) genome-wide screens yielded one or more reactive HSV-1 ORFs, with a range from 0 to a maximum of 13 for HLA-A*3503 in participant 6 , and a mean \pm SD of $5.2 \pm 2.3,3.5 \pm 3.8$, and $0.6 \pm 1.0$ CD8 ORFlevel hits in individual HLA-A, -B, and -C allele screens, respectively.

HSV-1 ORFs eliciting CD8 responses enriched by cross-presentation. Overall, 40 distinct HSV-1 polypeptides were found to elicit CD8 ${ }^{+}$ IFN- $\gamma$ responses among the 7 participants. This represents $54 \%$ of the 74 unique proteins studied (Figure 6). These proteins had diverse expression kinetics, structural, and functional roles, as briefly annotated (Supplemental Table 2) and detailed in the primary literature (reviewed in ref. 1). Each immediate early protein expressed with $\alpha$ kinetics was represented, except for ICP47, a short polypeptide, as were early, leaky late, and true late polypeptides. Nonstructural proteins and structural proteins in the capsid, tegument, and envelope were all targeted by $\mathrm{CD}^{+} \mathrm{T}$ cells. The most population-prevalent CD8 antigen was encoded by UL39. This 1,137-amino-acid-long polypeptide is the large subunit of ribonucleotide reductase, is not detected in virions, and is a virulence 


\section{Table 2}

Direct ex vivo expression of intracellular IFN- $\gamma$ or surface CD137 by live, CD3 ${ }^{+} C D 8+$ cells after cross-presentation by autologous moDCs loaded with HSV-1 or control antigen

\begin{tabular}{|c|c|c|c|c|c|c|}
\hline \multirow[b]{2}{*}{ Individual } & \multicolumn{3}{|c|}{ IFN- $\gamma$} & \multicolumn{3}{|c|}{ CD137 } \\
\hline & Mock & HSV-1 & Net & Mock & HSV-1 & Net \\
\hline \multicolumn{7}{|c|}{ HSV-seropositive } \\
\hline 1 & 0.08 & 0.59 & 0.51 & 0.54 & 1.68 & 1.14 \\
\hline 2 & Not done & Not done & Not done & 0.12 & 2.63 & 2.51 \\
\hline 3 & 0.07 & 0.11 & 0.04 & 0.22 & 1.93 & 1.71 \\
\hline 4 & 0.01 & 0.10 & 0.09 & 0.12 & 0.52 & 0.40 \\
\hline 5 & 0.01 & 0.19 & 0.18 & 0.51 & 0.78 & 0.27 \\
\hline 6 & 0.16 & 2.54 & 2.38 & 0.21 & 2.96 & 2.75 \\
\hline 7 & 0.07 & 0.19 & 0.12 & 0.23 & 1.52 & 1.29 \\
\hline \multicolumn{7}{|c|}{ HSV-seronegative } \\
\hline 12 & 0.07 & 0.08 & 0.01 & 0.32 & 0.50 & 0.18 \\
\hline 13 & 0.24 & 0.78 & 0.54 & 0.48 & 2.29 & 1.81 \\
\hline 14 & 0.05 & 0.03 & -0.02 & 0.14 & 0.14 & -0.01 \\
\hline
\end{tabular}

detected (Supplemental Figure 2C). In contrast, we demonstrated CD8 recognition of gB1 by 6 distinct HLA alleles and in 4 of 7 individuals.

Definition of HSV-1 peptide epitopes recognized by $C D 8^{+}$ $T$ cells enriched by cross-presentation. To test for the presence of discrete peptide epitopes, we selected a subset of the CD8 antigens (Figure 6) that used HLA alleles with high population prevalence and had well-developed peptide binding prediction algorithms. We tested peptides from 24 distinct HSV-1 ORFs for potential HLA-A*0101-, -A*0201-, -A*2402-, -A*2902-, or $-B * 0702$-restricted peptide epitopes. Bulk CD137hi_ selected $\mathrm{CD}^{+}$cells were tested for IFN- $\gamma$ expression by intracellular cytokine cytometry (ICC) using autologous PBMCs as APCs. DMSO negative control gave very low background, such that tight groupings of IFN $-\gamma^{+}$ $\mathrm{CD}^{+} \mathrm{T}$ cells could be discerned for antigenic peptides (representative data, Figure 5; full data, Supplemental Figure 3). Overlapping reactive 9- and 10-mer peptides were tallied as a single novel epitope. Overall, we defined 45 distinct HSV-1 CD8 epitopes (Table 4) in 22 ORFs. Several reactive ORFs had more than one constituent

factor in vivo but dispensable in vitro. UL39 was recognized in 11 of the 39 screens, in 6 of the 7 individuals, and was restricted by 7 distinct HLA alleles: A*0101, A*0201, A*2402, A*6801, B*3503, $B * 5801$, and Cw0202. The next most prevalently recognized protein was encoded by the abundant virion structural protein VP11/12, which is encoded by UL46. This protein is nonessential in vitro (1). UL46 was recognized in 10 screens and 5 participants and also restricted by 7 distinct alleles: $A^{*} 0101, A^{*} 0201, A^{*} 2402$, $A^{*} 2601, A^{*} 2902, B^{*} 4402$, and B*5101.

CD8 responses to HSV-1 proteins $\mathrm{gD} 1$ and $\mathrm{gB} 1$ were of special interest because they share high sequence homology with HSV-2 proteins that have been used as vaccine candidates (2, 43-45). HLA$A * 0201-$ restricted CD8 epitopes have been previously reported in both HSV-1 and HSV-2 $(16,17)$. Both proteins were well expressed in the pEXP103 system (Supplemental Figure 2, A and B). Two of 39 HLA-level screens showed reactivity with gD1 (Figure 6), for either HLA-B*1516 or HLA-B*3503. Among the 4 individuals with HLA-A*0201 or a close variant, none had $A^{*} 0201$-restricted responses to gD1. We additionally tested polyclonal HSV-reactive $\mathrm{CD}^{+} \mathrm{T}$ cell lines from these individuals with three previously reported (16) $\mathrm{A}^{*} 0201$-restricted synthetic peptides in $\mathrm{gD}$ that are sequence-identical in HSV-1 and HSV-2. Responses were not

\section{CD8 peptide epitope (Table 4).}

$C D 8$ responses in direct $P B M C$ assays. The $\mathrm{CD}^{+} \mathrm{T}$ cell line data above are qualitative rather than quantitative. The enrichment afforded by cross-presentation and cell selection could detect responses that were below the limit of detection in direct PBMC samples, and there is also the possibility we were detecting in vitro priming by moDCs. Epitope-specific responses in direct PBMC assays cannot represent in vitro priming and are amenable to detailed phenotypic studies using tetramers and ICC. We therefore used IFN- $\gamma$ ELISPOT to survey and rank epitope-specific responses for further studies. PBMCs from 20 HLA-appropriate individuals with HSV-1 infection were matched with CD8 peptide epitopes with known HLA restriction. We tested 40 of the 45 CD8 epitopes (Table 4) as detailed in Methods. The participants included the discovery cohort (Table 1) and 13 additional HSV-1-infected individuals. Each individual had a strong IFN- $\gamma$ response to whole UV HSV-1 antigen (likely $\mathrm{CD}^{+}$cells) and no spot-forming units (SFU) for DMSO negative control (data not shown).

Among 256 HLA-matched combinations of PBMCs and HSV-1 peptides in the overall set, $23(9.0 \%)$ were positive (red cells with integers in Figure 7). Twelve of 20 (60\%) individuals had from 1 to 5 peptide-specific responses in direct PBMC testing. Among the 40

\section{Table 3}

Recognition of HSV-1 by polyclonal, twice mitogen-expanded CD3+CD8+ PBMCs selected on the basis of CD137 expression after cross-presentation of HSV-1 by moDCs

\begin{tabular}{lcc} 
IFN- $\gamma$ expression in response & $\begin{array}{c}\text { exp } \\
\text { to autologous B-LCLS } \pm \text { HSV infection } \\
\text { Plock }\end{array}$ & HSV-1 \\
Person & 0.5 & 45.6 \\
1 & 0.2 & 4.4 \\
2 & 0.4 & 4.6 \\
3 & 0.4 & 14.8 \\
4 & 0.3 & 4.4 \\
5 & 0.5 & 16.1 \\
6 & 2.4 & 8.4 \\
7 & & \\
\hline
\end{tabular}

\begin{tabular}{ccc}
\multicolumn{3}{c}{$\begin{array}{c}\text { Cytotoxicity against autologous } \\
\text { B-LCLS } \pm \text { HSV infection }\end{array}$} \\
Mock & HSV-1 & HSV-2 \\
-1.5 & 52.8 & 1.5 \\
2.7 & 16.5 & 0.8 \\
1.6 & 46.1 & 2.4 \\
-0.6 & 53.9 & 0.2 \\
-0.2 & 8.9 & -2.8 \\
5.8 & 16.8 & -4.3 \\
1.8 & 55.9 & 9.2
\end{tabular}

\begin{tabular}{ccc}
\multicolumn{3}{c}{ Cytotoxicity against allogeneic } \\
\multicolumn{3}{c}{ B-LCLs \pm HSV infection } \\
Mock & HSV-1 & HSV-2 \\
9.7 & -1.3 & 8.5 \\
10.2 & 4.9 & 4 \\
4.3 & 3.6 & 5.6 \\
2.7 & 3.4 & 3.6 \\
14.8 & 0.4 & -3.4 \\
-3.2 & 8.1 & -0.2 \\
26 & 1.6 & 8.3
\end{tabular}



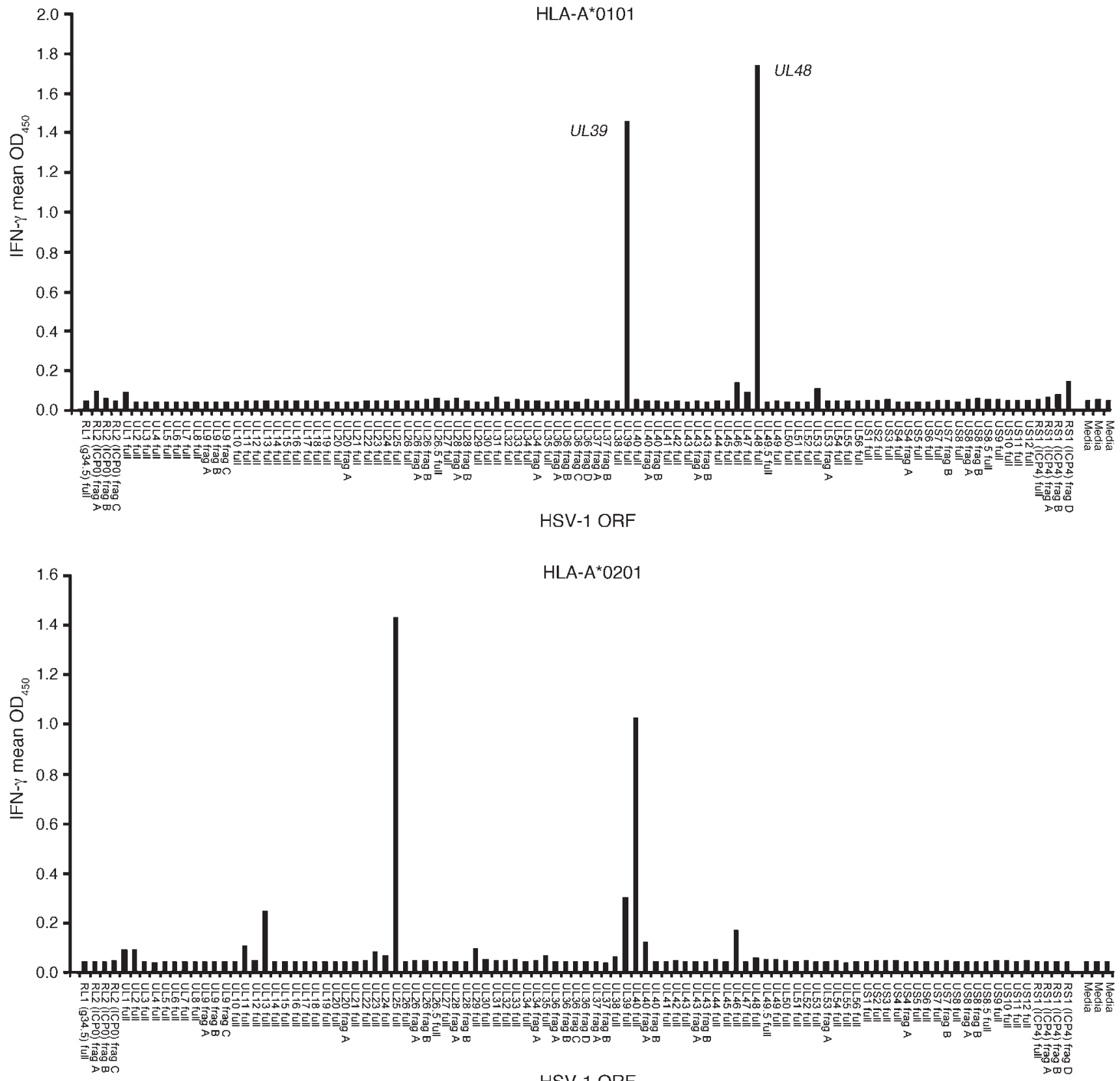

Figure 2

Representative data from participant 1 (Table 1) for CD8 ${ }^{+}$T cell reactivity with HSV-1 ORFs and peptides. IFN- $\gamma$ secretion by polyclonal expanded responder cell line derived from $C D 3^{+} C D 137^{\text {hi }}$ cells exposed to aAPCs expressing the indicated HLA-A molecules and the HSV-1 ORFs arrayed in nominal genomic order on the $x$ axis. The names of HSV-1 ORFs driving two representative positive responses are indicated for HLA-A*0101.

CD8 peptide epitopes tested, 12 (30\%) were positive in 1 or more HLA-matched individuals. The number of net IFN- $\gamma$ ELISPOT ${ }^{+}$ cells ranged from 11 to $136 \mathrm{SFU} / 10^{6}$ PBMCs. The highest rate of positivity was for the HLA-A*0201 peptides, with 6 of 9 epitopes positive in at least 1 individual, and 2 individuals positive for 4 distinct $A^{*} 0201$ peptides. The "hits" in the HLA-ORF screens that were confirmed by direct PBMC testing were biologically present above the threshold of the direct ELISPOT test. Some individuals with positive ORF-level responses in HLA-specific screens (red in
Figure 6) did not react with the peptides tested (blue in Figure 7). Peptide-reactive cells could be present below the limit of detection ex vivo. Alternatively, one or more undiscovered HLA-restricted epitopes accounted for the ORF-level positive responses (Figure 6).

$H S V-1$ ORFs stimulating population-prevalent CD4 responses. As noted above, measurement of unmanipulated PBMCs is limited by the low frequency of HSV-1-reactive $\mathrm{CD}^{+}$cells and the need for highly purified recombinant proteins or a very large peptide set. We therefore enriched and expanded HSV-1-reactive CD4+ 

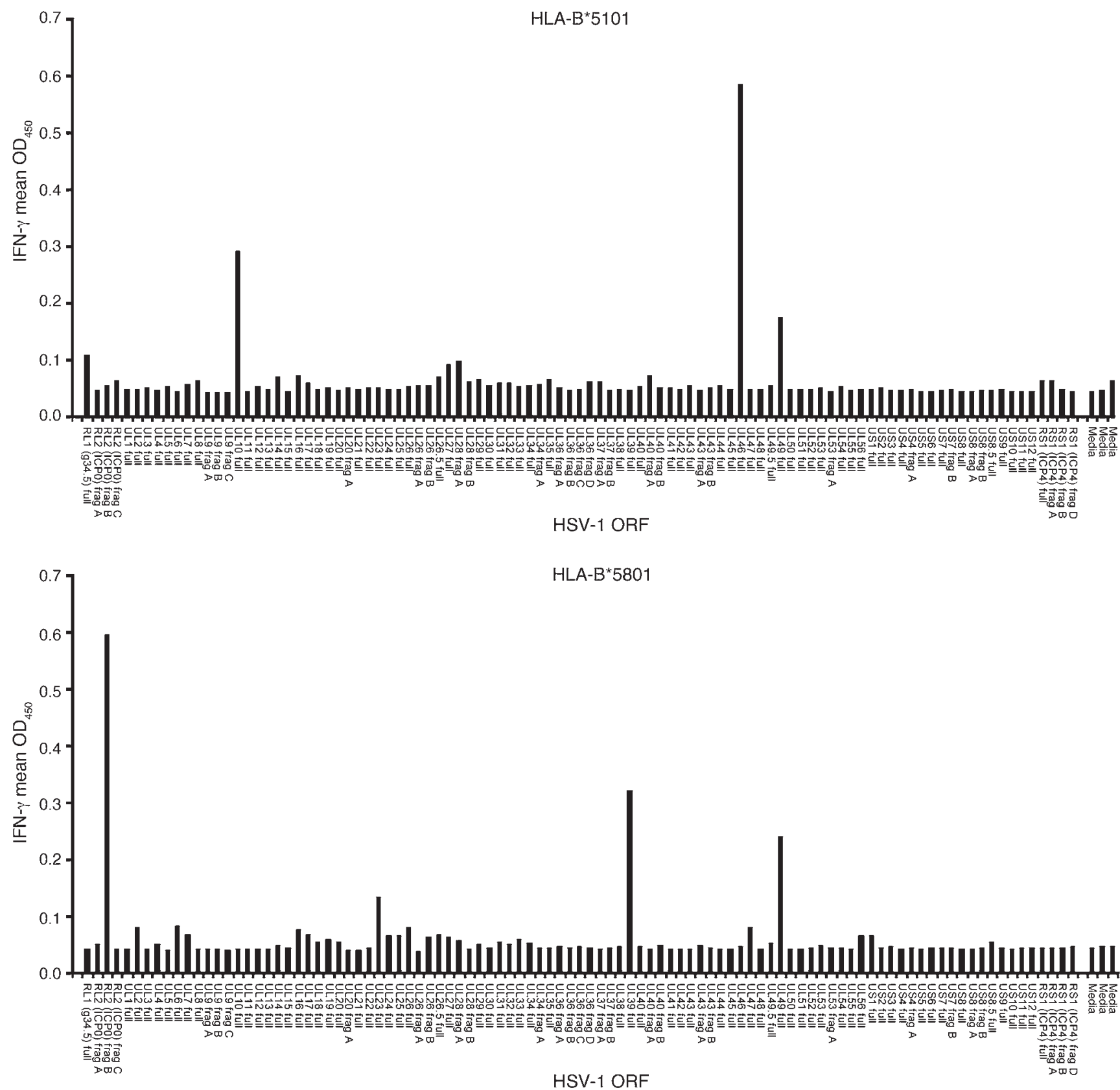

Figure 3

Representative data from participant 1 (Figure 2 and Table 1) for CD8 ${ }^{+}$T cell reactivity with HSV-1 ORFs and peptides. IFN- $\gamma$ secretion by polyclonal expanded responder cell line derived from $C D 3^{+} C D 137^{\text {hi }}$ cells exposed to aAPCs expressing the indicated HLA-B molecules and the HSV-1 ORFs arrayed in nominal genomic order on the $x$ axis.

$\mathrm{T}$ cells using protocols designed to yield large numbers of polyclonal responder cells. The initial stimulation used whole, cell-associated, UV-killed HSV-1, a format previously shown to restimulate $\mathrm{CD} 4^{+} \mathrm{T}$ cells specific for a variety of structural and nonstructural proteins in the context of HSV-2 (46). After 20 hours, a small percentage of live $\mathrm{CD}^{+}{ }^{+} \mathrm{CD} 4^{+}$cells in PBMCs specifically expressed CD137 (representative participant, Figure 8A). Cell lines created by sort purification and expansion with nonspecific mitogens were highly enriched for HSV-1-reactive
$\mathrm{CD}^{+}$cells, while sorted CD137lo cells were nonreactive (Figure 8A shows data after 2 cell expansions; enrichment was similar after the first expansion, data not shown).

We expressed proteins covering the large majority of the HSV-1 proteome (Supplemental Table 1) using an in vitro bacterial expression system. Anti-6-His IB showed specific staining (data not shown). We titered the ORFeome set in preliminary proliferation assays and found that a dilution of 1:5,000 it gave optimal responses with low background (data not shown). We further 

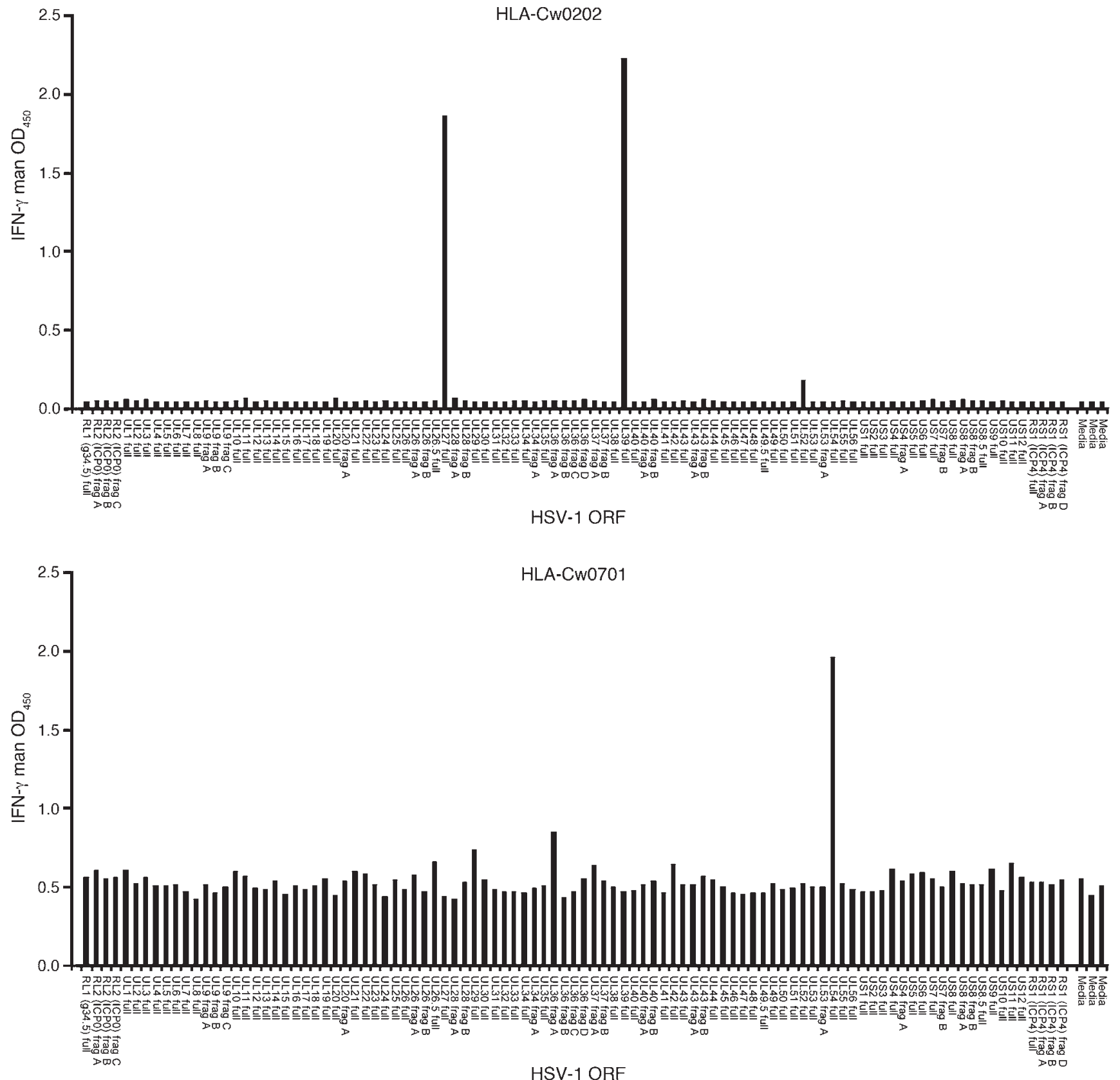

Figure 4

Representative data from participant 1 (Figures 2 and 3 and Table 1) for CD8 ${ }^{+}$T cell reactivity with HSV-1 ORFs and peptides. IFN- $\gamma$ secretion by polyclonal expanded responder cell line derived from $C D 3^{+} C D 137$ hi cells exposed to aAPCs expressing the indicated HLA-C molecules and the HSV-1 ORFs arrayed in nominal genomic order on the $x$ axis.

checked potency and identity with a $\mathrm{CD}^{+} \mathrm{T}$ cell clone specific for HSV-1 protein VP22 (gene UL49) (18) and noted strong, specific responses (Supplemental Figure 4).

Polyclonal CD137hi $\mathrm{CD}^{+}$cell lines showed discrete patterns of reactivity when assayed against the protein set (representative participant, Figure $8 \mathrm{~B}$ ) in each of 11 individuals, including those with detailed CD8 studies (Table 1). The average number of HSV-1 ORFs recognized per individual was $22.8 \pm 7.0$ (mean $\pm \mathrm{SD}$ ). Overall, 52 of the $74(70 \%)$ unique HSV-1 polypeptides were recognized at least once. On a population basis, the most prevalent $\mathrm{CD} 4$ responses were noted for envelope glycoproteins gB1 and gD1, and tegument protein VP11/12, encoded by gene UL46, discussed above for CD8 ${ }^{+}$cells. Each was recognized by 11 of 11 individuals (100\%). Inspection of the overlap between CD8 and CD4 antigens (Figure 9) showed that the proteins encoded by UL39 and UL46 were frequently recognized. Grouping of HSV-1 proteins by their kinetics of expression during viral replication (1) indicates that true late proteins are less commonly recognized by $\mathrm{CD}^{+}$cells than are proteins in other classes. 


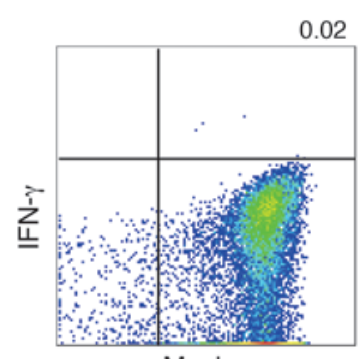

CD8

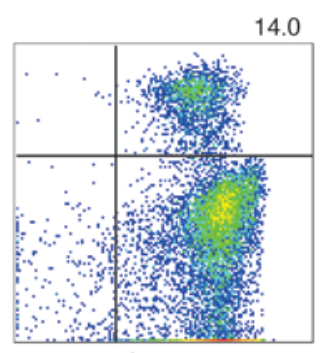

SEB

14.0

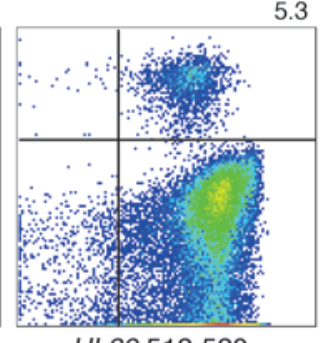

UL39 512-520

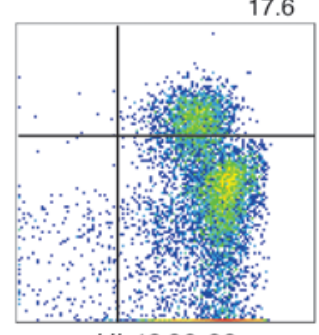

UL48 90-99
17.6

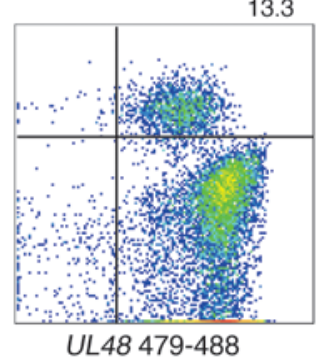

Figure 5

Representative analyses of polyclonal HSV-1-reactive CD8 ${ }^{+}$cells from the same individual represented in Figures 2-4 probed for reactivity with individual HSV-1 peptides derived from the ORFs indicated below the plots, or negative or positive controls (Mock and SEB). Numbers are percentages of cells in the upper-right quadrants.

Application to vaccinia virus. Participant 9 from a previous report (47) was re-vaccinated with vaccinia 20 months prior to phlebotomy. Using cross-presentation for $\mathrm{CD}^{+} \mathrm{T}$ cells, followed by CD137 detection outlined exactly as done for HSV-1, we detected low but specific CD 8 reactivity at 20 hours. Selected, expanded CD137hi but not $\mathrm{CD} 137^{\text {lo }}$ cells were highly enriched in vaccinia virus-specific $\mathrm{CD}^{+} \mathrm{T}$ cells (Figure 10A), and these cells had specific cytotoxicity (Figure 10B). Participant 8 (47), who had been re-vaccinated 40 months prior to study, was studied for CD4 responses. We used UV-inactivated whole vaccinia virus and CD137-based selection, again as detailed for HSV-1. The CD137hi-origin bulk cells were very highly enriched for T cells making IFN- $\gamma$ with or without IL-2 in response to vaccinia, while these were essentially absent from CD137lo cells (Figure 10C). All cell populations responded to the positive control PMA/ionomycin stimulation, albeit with varying cytokine patterns. Similar results were obtained for several vaccinia-immune individuals. The $\mathrm{CD}^{+}$and $\mathrm{CD}^{+} \mathrm{T}$ cell enrichment methods (outlined in Figure 11) are thus applicable to two largegenome microbes. Downstream CD4 analyses showed responses to discrete vaccinia ORFs (unpublished observations).

\section{Discussion}

HSV-1 is an important human pathogen, but there are no vaccines in active clinical development. In this report, we have shown that the proteins encoded by HSV-1 genes UL39 and UL46 have coordinated CD8 and CD4 immunogenicity in most individuals and are therefore rational vaccine candidates. We have provided an estimate of the complexity of the response, documented clustering of responses based on HLA type, and defined more than 40 novel CD8 $\mathrm{T}$ cell epitopes. We have identified a new hierarchy of responses based on HLA locus, with HLA-A more frequently responsible for antigen presentation than HLA-B, and HLA C having a minor contribution. Parallel studies determined that infected humans recognize a mean of 17 and 23 HSV-1 ORFs as CD8 and CD4 antigens, respectively. With the exceptions noted in the Introduction and Results, to our knowledge, the vast majority of the antigenic reactivities and epitopes we have defined are novel. We also showed applicability to another large-genome virus and anticipate that these systems may be useful for many pathogens.

$\mathrm{T}$ cell responses to pathogens have been difficult to access for several reasons. Microbe-specific T cells can occur at low abundance in the blood, such that an unbiased pre-enrichment step is helpful for new antigen or epitope discovery. Sylwester et al.'s probe of the response to the CMV proteome using peptides and direct PBMC ICC was enabled by the high overall abundance of T cell responses to CMV (48). Responses to EBV are also large, such that a direct PBMC approach to CD8 responses using a cloned partial ORFeome has yielded hits (49). Indeed, the low magnitude of direct PBMC IFN- $\gamma$ ELISPOT responses to single HSV- 1 peptides in the current report contrast with the high-magnitude responses to single epitopes noted in CMV and $\operatorname{EBV}(48,50)$.

We have shown that restimulation methods tailored for $\mathrm{CD}^{+}$ or $\mathrm{CD}^{+} \mathrm{T}$ cells, based on the biology of antigen presentation, can be used without change for two distinct viruses. Once responder cells are enriched and expanded, the large microbial genomes still harbor myriad potential epitopes that are challenging to decode. In this report, we first assigned CD8 reactivity at the level of HSV-1 ORFs, using efficient plasmid sets. Limited use of peptide binding algorithms and peptide synthesis efficiently confirmed antigenicity to the epitope level. The new, validated peptide reagents were in turn positive in a proportion of additional HLA-appropriate subjects in direct ex vivo assays. Even in our limited study population, $\mathrm{CD}^{+} \mathrm{T}$ cells from different individuals frequently had reactivity, in our primary co-transfection screens, with the same HSV-1 ORFs when studied using shared HLA cDNA molecules. For example, each HLA-A*0101-bearing donor had $\mathrm{CD}^{+} \mathrm{T}$ cells recognizing the HSV-1 ORFs UL1 and UL48 (Figure 6). Clustering studies to measure this tendency will be the subject of future analyses.

In addition to identifying $U L 39$ and $U L 46$ as rational candidate subunit vaccines, our data have implications for the design of whole virus formats. In fact, the diversity of the CD8 response, with an average of 17 antigens per person, implies that a whole virus rather than a subunit approach to vaccination for HSV-1 is most likely to mimic the immune response to natural infection. Globally, we found that broad kinetic and structural and functional spectra of HSV-1 proteins were recognized by the human CD8 response. Therefore, either replication-incompetent or attenuated replication-competent vaccine formats have the potential to stimulate broad CD8 responses in most individuals. Among whole HSV vaccine candidates that replicate discontinuously in normal cells, those that allow expression to proceed relatively completely may be quite rational $(25,26)$. To explore the virological rules of HSV-1 T cell antigenicity, we scored each protein dichotomously for CD8 responses in the study population, and then categorized each protein studied as immediate early, early, late but not otherwise characterized, early late with 
HLA allele

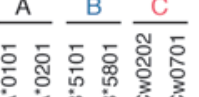

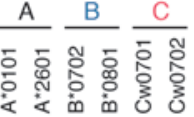

$\begin{array}{llllll}0 & 0 & 0 & 0 & 0 & 0\end{array}$

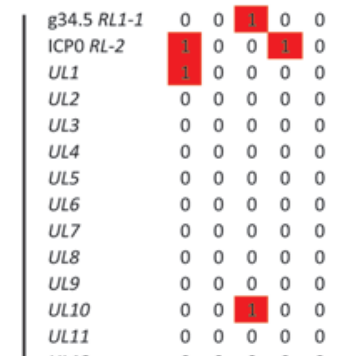

$\begin{array}{lllllll}0 & 0 & 1 & 0 & 0 & 0\end{array}$

$\begin{array}{lllllll}0 & 0 & 1 & 0 & 0 & 0 \\ 1 & 0 & 0 & 0 & 0 & 0\end{array}$ $\begin{array}{llllll}0 & 0 & 0 & 0 & 0 & 0\end{array}$ $\begin{array}{llllll}0 & 0 & 0 & 0 & 0 & 0\end{array}$ $\begin{array}{llllll}0 & 0 & 0 & 0 & 0 & 0\end{array}$ $\begin{array}{llllll}0 & 0 & 0 & 0 & 0 & 0\end{array}$ $\begin{array}{llllll}0 & 0 & 0 & 0 & 0 & 0\end{array}$ $\begin{array}{llllll}0 & 0 & 0 & 0 & 0 & 0\end{array}$ $\begin{array}{llllll}0 & 0 & 0 & 0 & 0 & 0\end{array}$ $\begin{array}{llllll}0 & 1 & 0 & 0 & 0 & 0\end{array}$ $\begin{array}{llllll}0 & 0 & 0 & 0 & 0 & 0\end{array}$ $\begin{array}{llllll}0 & 0 & 0 & 0 & 0 & 0\end{array}$ $\begin{array}{llllll}0 & 0 & 0 & 0 & 0 & 0\end{array}$ $\begin{array}{llllll}0 & 0 & 0 & 0 & 0 & 0\end{array}$ $\begin{array}{llllll}0 & 0 & 0 & 0 & 0 & 0\end{array}$ $\begin{array}{llllll}0 & 0 & 0 & 0 & 0 & 0\end{array}$ $\begin{array}{llllll}0 & 0 & 0 & 0 & 0 & 0\end{array}$ $\begin{array}{llllll}0 & 0 & 0 & 0 & 0 & 0\end{array}$ $\begin{array}{llllll}0 & 0 & 0 & 0 & 0 & 0\end{array}$ $\begin{array}{llllll}0 & 0 & 0 & 0 & 0 & 0\end{array}$ $\begin{array}{llllll}0 & 0 & 0 & 0 & 0 & 0\end{array}$ $\begin{array}{llllll}0 & 0 & 0 & 0 & 0 & 0\end{array}$ $\begin{array}{llllll}0 & 0 & 0 & 0 & 0 & 0\end{array}$ $\begin{array}{llllll}0 & 0 & 0 & 0 & 0 & 0\end{array}$ $\begin{array}{llllll}0 & 0 & 0 & 0 & 0 & 0\end{array}$ $\begin{array}{llllll}0 & 0 & 0 & 0 & 0 & 0\end{array}$ $\begin{array}{llllll}0 & 0 & 0 & 0 & 0 & 0\end{array}$ $\begin{array}{llllll}0 & 0 & 0 & 0 & 0 & 0\end{array}$ $\begin{array}{llllll}0 & 0 & 0 & 0 & 0 & 0\end{array}$ $\begin{array}{llllll}0 & 0 & 0 & 0 & 0 & 0\end{array}$ $\begin{array}{llllll}0 & 0 & 0 & 0 & 0 & 0\end{array}$ $\begin{array}{llllll}0 & 0 & 0 & 0 & 0 & 0\end{array}$ $\begin{array}{llllll}0 & 0 & 0 & 0 & 0 & 0\end{array}$ $\begin{array}{llllll}0 & 0 & 0 & 0 & 0 & 0\end{array}$ $\begin{array}{llllll}0 & 0 & 0 & 0 & 0 & 0\end{array}$ $\begin{array}{llllll}0 & 0 & 0 & 0 & 0 & 0\end{array}$ $\begin{array}{llllll}0 & 0 & 0 & 0 & 0 & 0\end{array}$ $\begin{array}{llllll}0 & 0 & 0 & 0 & 0 & 0\end{array}$ 01000000 $\begin{array}{llllll}0 & 0 & 0 & 0 & 0 & 0 \\ 1 & 0 & 0 & 0 & 0 & 0\end{array}$ $\begin{array}{lllll}0 & 0 & 0 & 0 & 0\end{array}$ $\begin{array}{lllll}0 & 0 & 0 & 0 & 0\end{array}$ $\begin{array}{llllll}0 & 0 & 0 & 0 & 0 & 0 \\ 0 & 0 & 0 & 0 & 0 & 0\end{array}$ $\begin{array}{llllll}0 & 0 & 0 & 0 & 0 & 0\end{array}$ $\begin{array}{llllll}0 & 0 & 0 & 0 & 0 & 0 \\ 1 & 1 & 0 & 0 & 0 & 0\end{array}$ $\begin{array}{llllll}0 & 0 & 0 & 0 & 0 & 0\end{array}$ 10000000 $\begin{array}{llllll}0 & 0 & 0 & 0 & 0 & 0\end{array}$ $\begin{array}{llllll}0 & 0 & 0 & 0 & 0 & 0\end{array}$ $\begin{array}{llllll}0 & 0 & 0 & 0 & 0 & 0\end{array}$ $\begin{array}{llllll}0 & 0 & 0 & 0 & 0 & 0\end{array}$ $\begin{array}{lllll}0 & 0 & 0 & 0 & 0\end{array}$ $\begin{array}{llllll}0 & 0 & 0 & 0 & 0 & 0\end{array}$ $\begin{array}{llllll}0 & 0 & 0 & 0 & 0 & 0\end{array}$ $\begin{array}{llllll}0 & 0 & 0 & 0 & 0 & 0\end{array}$ $\begin{array}{llllll}0 & 0 & 0 & 0 & 0 & 0\end{array}$ $\begin{array}{llllll}0 & 0 & 0 & 0 & 0 & 0\end{array}$ $\begin{array}{llllll}0 & 0 & 0 & 0 & 0 & 0\end{array}$ $\begin{array}{llllll}0 & 0 & 0 & 0 & 0 & 0\end{array}$ $\begin{array}{llllll}0 & 0 & 0 & 0 & 0 & 0\end{array}$ $\begin{array}{llllll}0 & 0 & 0 & 0 & 0\end{array}$ $\begin{array}{llllll}0 & 0 & 0 & 0 & 0 & 0\end{array}$ $\begin{array}{llllll}0 & 0 & 0 & 0 & 0 & 0\end{array}$ $0 \begin{array}{llllll}0 & 1 & 0 & 0 & 0 & 0\end{array}$

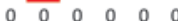
$\begin{array}{llllll}0 & 0 & 0 & 0 & 0 & 0\end{array}$ $\begin{array}{llllll}0 & 0 & 0 & 0 & 0 & 0\end{array}$ $\begin{array}{llllll}0 & 0 & 0 & 0 & 0 & 0\end{array}$ \begin{tabular}{llllll}
0 & 0 & 0 & 0 & 0 & 0 \\
0 & 0 & 0 & 0 & 0 & 0 \\
\hline
\end{tabular}

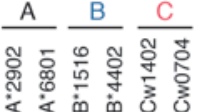

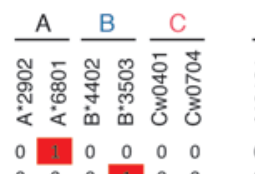

$\begin{array}{lllll}0 & 0 & 0 & 0 & 0\end{array}$

$\begin{array}{llllll}0 & 0 & 0 & 0 & 0 & 0\end{array}$ $\begin{array}{lllll}0 & 0 & 0 & 0 & 0\end{array}$ $\begin{array}{llllll}0 & 0 & 0 & 0 & 0 & 0\end{array}$ $\begin{array}{lllll}0 & 0 & 0 & 0 & 0\end{array}$ $\begin{array}{lllll}0 & 0 & 0 & 0 & 0\end{array}$ $\begin{array}{llllll}0 & 0 & 0 & 0 & 0 & 0\end{array}$ $\begin{array}{llllll}0 & 0 & 0 & 0 & 0 & 0\end{array}$ $\begin{array}{llllll}0 & 0 & 0 & 0 & 0 & 0\end{array}$ $\begin{array}{llllll}0 & 0 & 0 & 0 & 0 & 0\end{array}$ $\begin{array}{lllllllllllllllllll}0 & 0 & 1 & 0 & 0 & 0\end{array}$ $\begin{array}{llllll}0 & 0 & 1 & 0 & 0 & 0 \\ 0 & 0 & 0 & 0 & 0 & 0\end{array}$ $\begin{array}{lllllll}0 & 0 & 0 & 1 & 0 & 0\end{array}$ $\begin{array}{lllllll}0 & 0 & 0 & 0 & 0 & 0\end{array}$ $\begin{array}{llllll}0 & 0 & 0 & 0 & 0 & 0\end{array}$ $\begin{array}{llllll}0 & 0 & 0 & 0 & 0 & 0\end{array}$ $\begin{array}{llllll}0 & 0 & 0 & 0 & 0 & 0\end{array}$ $\begin{array}{llllll}0 & 0 & 0 & 0 & 0 & 0\end{array}$ $\begin{array}{llllll}0 & 0 & 0 & 0 & 0 & 0 \\ 0 & 1 & 0 & 1 & 0 & 0\end{array}$

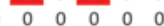
$\begin{array}{lllll}0 & 0 & 0 & 0 & 0\end{array}$ $\begin{array}{llllll}0 & 0 & 0 & 0 & 0 & 0\end{array}$ $\begin{array}{llll}0 & 0 & 0 & 0\end{array}$ $\begin{array}{lllll}0 & 0 & 0 & 0 & 0\end{array}$ $\begin{array}{lllll}0 & 0 & 0 & 0 & 0\end{array}$ $\begin{array}{llllll}0 & 0 & 0 & 0 & 0 & 0\end{array}$ $\begin{array}{llllll}0 & 0 & 0 & 0 & 0 & 0\end{array}$ $\begin{array}{lllll}0 & 0 & 0 & 0 & 0\end{array}$

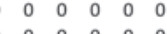
$\begin{array}{llll}0 & 0 & 0 & 0\end{array}$ $\begin{array}{lllll}0 & 0 & 0 & 0 & 0\end{array}$ $\begin{array}{llllll}0 & 0 & 0 & 0 & 0 & 0 \\ 0 & 1 & 0 & 0 & 0 & 0\end{array}$ $\begin{array}{lllll}0 & 0 & 0 & 0 & 0\end{array}$ $\begin{array}{lllll}0 & 0 & 0 & 0 & 0\end{array}$ $\begin{array}{lllll}0 & 0 & 0 & 0 & 0\end{array}$ $\begin{array}{llllll}0 & 0 & 0 & 0 & 0 & 0\end{array}$ $\begin{array}{lllllll}0 & 0 & 0 & 0 & 0 & 0\end{array}$ $\begin{array}{lllll}0 & 0 & 0 & 0 & 0\end{array}$ $\begin{array}{llllll}0 & 0 & 0 & 0 & 0 & 0\end{array}$ $\begin{array}{llllll}0 & 0 & 0 & 0 & 0 & 0\end{array}$ $\begin{array}{lllll}0 & 0 & 0 & 0 & 0\end{array}$ $\begin{array}{llllll}0 & 0 & 0 & 0 & 0 & 0 \\ 1 & 0 & 0 & 1 & 0 & 0\end{array}$ 100000 $\begin{array}{lllllll}0 & 0 & 0 & 0 & 0 & 0\end{array}$ $\begin{array}{lllll}0 & 0 & 0 & 0 & 0\end{array}$ $\begin{array}{llllll}0 & 0 & 0 & 0 & 0 & 0\end{array}$ $\begin{array}{lllll}0 & 0 & 0 & 0 & 0\end{array}$ $\begin{array}{lllll}0 & 0 & 0 & 0 & 0\end{array}$ $\begin{array}{lllll}0 & 0 & 0 & 0 & 0\end{array}$ $\begin{array}{llllll}0 & 0 & 0 & 0 & 0 & 0\end{array}$ $\begin{array}{llll}0 & 0 & 0 & 0\end{array}$ $\begin{array}{lllll}0 & 0 & 0 & 0 & 0\end{array}$ $\begin{array}{lllll}0 & 0 & 0 & 0 & 0\end{array}$ $\begin{array}{llllll}0 & 0 & 0 & 0 & 0 & 0\end{array}$ $\begin{array}{lllll}0 & 0 & 0 & 0 & 0\end{array}$ $\begin{array}{lllll}0 & 0 & 0 & 0 & 0\end{array}$ $\begin{array}{llllll}0 & 0 & 0 & 0 & 0 & 0 \\ 0 & 0 & 1 & 0 & 0 & 0\end{array}$ $\begin{array}{llllll}0 & 0 & 0 & 0 & 0 & 0\end{array}$ $\begin{array}{llllll}0 & 0 & 0 & 0 & 0 & 0\end{array}$ $\begin{array}{llllll}0 & 0 & 0 & 0 & 0 & 0 \\ 0 & 1 & 0 & 0 & 0 & 0\end{array}$ $\begin{array}{lllll}0 & 0 & 0 & 0 & 0\end{array}$ $\begin{array}{lllll}0 & 0 & 0 & 0 & 0\end{array}$ $\begin{array}{llllll}0 & 0 & 0 & 0 & 0 & 0\end{array}$ \begin{tabular}{llllll}
0 & 0 & 0 & 0 & 0 & 0 \\
\hline
\end{tabular}

$\begin{array}{lllllll}0 & 0 & 0 & 1 & 0 & 0\end{array}$ $\begin{array}{llllll}0 & 0 & 0 & 0 & 0 & 0\end{array}$ $\begin{array}{llllll}0 & 0 & 0 & 0 & 0 & 0\end{array}$ $\begin{array}{llllll}0 & 0 & 0 & 0 & 0 & 0\end{array}$ $\begin{array}{llllll}0 & 0 & 0 & 0 & 0 & 0\end{array}$ $\begin{array}{llllll}0 & 0 & 0 & 0 & 0 & 0\end{array}$ $\begin{array}{llllll}0 & 0 & 0 & 0 & 0 & 0\end{array}$ $\begin{array}{llllll}0 & 0 & 0 & 0 & 0 & 0\end{array}$ $\begin{array}{llllll}0 & 0 & 0 & 0 & 0 & 0\end{array}$ $\begin{array}{llllll}0 & 0 & 0 & 0 & 0 & 0\end{array}$ $\begin{array}{llllll}0 & 0 & 0 & 0 & 0 & 0\end{array}$ $\begin{array}{llllll}0 & 0 & 0 & 0 & 0 & 0\end{array}$ $\begin{array}{llllll}0 & 0 & 0 & 0 & 0 & 0\end{array}$ $\begin{array}{llllll}0 & 0 & 0 & 0 & 0 & 0\end{array}$ $\begin{array}{llllll}0 & 0 & 0 & 0 & 0 & 0\end{array}$ $\begin{array}{llllll}0 & 0 & 0 & 0 & 0 & 0\end{array}$ $\begin{array}{llllll}0 & 0 & 0 & 0 & 0 & 0\end{array}$ $\begin{array}{llllll}0 & 0 & 0 & 1 & 0 & 0 \\ 0 & 1 & 1 & 0 & 0 & 0\end{array}$ $\begin{array}{llllll}0 & 0 & 0 & 0 & 0 & 0\end{array}$ 100000 $\begin{array}{llllll}0 & 0 & 0 & 0 & 0 & 0\end{array}$ $\begin{array}{llllll}0 & 0 & 0 & 0 & 0 & 0\end{array}$ $\begin{array}{llllll}0 & 0 & 0 & 0 & 0 & 0\end{array}$ $\begin{array}{llllll}0 & 0 & 0 & 0 & 0 & 0\end{array}$ $\begin{array}{llllll}0 & 0 & 0 & 0 & 0 & 0\end{array}$ $\begin{array}{llllll}0 & 0 & 0 & 0 & 0 & 0\end{array}$ $\begin{array}{llllll}1 & 1 & 0 & 0 & 0 & 0 \\ 0 & 0 & 0 & 0 & 0 & 0\end{array}$ $\begin{array}{llllll}0 & 0 & 0 & 0 & 0 & 0 \\ 1 & 0 & 0 & 1 & 0 & 0\end{array}$ $\begin{array}{llllll}0 & 0 & 0 & 0 & 0 & 0\end{array}$ $\begin{array}{llllll}0 & 0 & 0 & 0 & 0 & 0\end{array}$ $\begin{array}{llllll}0 & 0 & 0 & 0 & 0 & 0\end{array}$ $\begin{array}{llllll}0 & 0 & 0 & 0 & 0 & 0 \\ 0 & 1 & 0 & 0 & 0 & 0\end{array}$ $\begin{array}{llllll}0 & 1 & 0 & 0 & 0 & 0 \\ 0 & 0 & 0 & 0 & 0 & 0\end{array}$ $\begin{array}{llllll}0 & 0 & 0 & 0 & 0 & 0\end{array}$ $\begin{array}{llllll}0 & 0 & 0 & 0 & 0 & 0\end{array}$ $\begin{array}{lllllll}0 & 0 & 0 & 1 & 0 & 0 \\ 0 & 1 & 0 & 1 & 0 & 0\end{array}$ $\begin{array}{llllll}0 & 0 & 0 & 0 & 0 & 0\end{array}$ $0 \begin{array}{llllll}0 & 1 & 0 & 0 & 0 & 0\end{array}$ $\begin{array}{llllll}0 & 0 & 0 & 0 & 0 & 0\end{array}$ $\begin{array}{llllll}0 & 0 & 0 & 0 & 0 & 0\end{array}$ $\begin{array}{llllll}0 & 0 & 0 & 0 & 0 & 0\end{array}$ $\begin{array}{llllll}0 & 0 & 0 & 0 & 0 & 0 \\ 0 & 0 & 0 & 0 & 0 & 0\end{array}$ $\begin{array}{llllll}0 & 0 & 0 & 0 & 0 & 0\end{array}$ $\begin{array}{llllll}0 & 0 & 0 & 0 & 0 & 0\end{array}$ $\begin{array}{llllll}0 & 0 & 0 & 0 & 0 & 0\end{array}$ $\begin{array}{llllll}0 & 1 & 0 & 0 & 0 & 0\end{array}$ $\begin{array}{llllll}0 & 0 & 0 & 0 & 0 & 0\end{array}$ $\begin{array}{llllll}0 & 0 & 0 & 0 & 0 & 0\end{array}$ $\begin{array}{llllll}0 & 0 & 0 & 0 & 0 & 0 \\ 0 & 0 & 0 & 1 & 0 & 0\end{array}$ $\begin{array}{llllll}0 & 0 & 0 & 1 & 0 & 0 \\ 0 & 0 & 0 & 0 & 0 & 0\end{array}$ $\begin{array}{llllll}0 & 0 & 0 & 0 & 0 & 0\end{array}$ $\begin{array}{lllllll}0 & 0 & 0 & 1 & 0 & 0\end{array}$ $\begin{array}{lllllll}0 & 0 & 0 & 0 & 0 & 0\end{array}$ $\begin{array}{llllll}0 & 0 & 0 & 0 & 0 & 0\end{array}$ $\begin{array}{llllll}0 & 0 & 0 & 0 & 0 & 0\end{array}$ $\begin{array}{llllllllllllllllll}0 & 0 & 0 & 1 & 0 & 0\end{array}$ $\begin{array}{llllll}0 & 0 & 0 & 0 & 0 & 0\end{array}$ $\begin{array}{llllll}0 & 0 & 0 & 0 & 0 & 0\end{array}$ $\begin{array}{llllll}0 & 0 & 0 & 0 & 0 & 0\end{array}$ $\begin{array}{llllll}0 & 0 & 0 & 0 & 0 & 0\end{array}$ $\begin{array}{llllll}0 & 0 & 0 & 0 & 0 & 0\end{array}$ \begin{tabular}{llllll}
0 & 0 & 0 & 0 & 0 & 0 \\
0 & 1 & 0 & 0 & 0 & 0 \\
\hline
\end{tabular} $\begin{array}{lllll}0 & 0 & 0 & 0 & 0\end{array}$

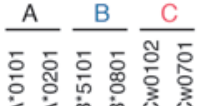 \\ $\begin{array}{llllll}0 & 0 & 0 & 0 & 0 & 0\end{array}$}

$\begin{array}{llllll}0 & 0 & 0 & 0 & 0 & 0\end{array}$ $\begin{array}{llllll}0 & 0 & 0 & 0 & 0 & 0\end{array}$ 01100000 $\begin{array}{llllll}0 & 0 & 0 & 0 & 0 & 0\end{array}$ $\begin{array}{llllll}0 & 0 & 0 & 0 & 0 & 0\end{array}$ $\begin{array}{llllll}0 & 0 & 0 & 0 & 0 & 0\end{array}$ $\begin{array}{llllll}0 & 0 & 0 & 0 & 0 & 0\end{array}$ $\begin{array}{llllll}0 & 0 & 0 & 0 & 0 & 0\end{array}$ $\begin{array}{llllll}0 & 0 & 0 & 0 & 0 & 0\end{array}$ $\begin{array}{llllll}0 & 0 & 0 & 0 & 0 & 0\end{array}$ $\begin{array}{llllll}0 & 0 & 0 & 0 & 0 & 0\end{array}$ $\begin{array}{llllll}0 & 0 & 0 & 0 & 0 & 0\end{array}$ $\begin{array}{llllll}0 & 0 & 0 & 0 & 0 & 0\end{array}$ $\begin{array}{llllll}0 & 0 & 0 & 0 & 0 & 0\end{array}$ $\begin{array}{llllll}0 & 0 & 0 & 0 & 0 & 0\end{array}$ $\begin{array}{llllll}0 & 0 & 0 & 0 & 0 & 0\end{array}$ $\begin{array}{llllll}0 & 0 & 0 & 0 & 0 & 0\end{array}$ $\begin{array}{llllll}0 & 0 & 0 & 0 & 0 & 0\end{array}$ $\begin{array}{llllll}0 & 0 & 0 & 0 & 0 & 0\end{array}$ $\begin{array}{llllll}0 & 0 & 0 & 0 & 0 & 0\end{array}$ $\begin{array}{llllll}0 & 0 & 0 & 0 & 0 & 0\end{array}$ $\begin{array}{llllll}0 & 0 & 0 & 0 & 0 & 0\end{array}$ $\begin{array}{llllll}0 & 0 & 0 & 0 & 0 & 0\end{array}$ $\begin{array}{llllll}0 & 0 & 0 & 0 & 0 & 0\end{array}$ $\begin{array}{llllll}0 & 0 & 0 & 0 & 0 & 0\end{array}$ $\begin{array}{llllll}0 & 0 & 0 & 0 & 0 & 0\end{array}$ $\begin{array}{llllll}0 & 0 & 0 & 0 & 0 & 0\end{array}$ $\begin{array}{lllllll}0 & 0 & 0 & 0 & 0 & 0\end{array}$ $\begin{array}{llllll}0 & 0 & 0 & 0 & 0 & 0\end{array}$ $\begin{array}{llllll}0 & 0 & 0 & 0 & 0 & 0\end{array}$ $\begin{array}{llllll}0 & 0 & 0 & 0 & 0 & 0\end{array}$ $\begin{array}{llllll}0 & 0 & 0 & 0 & 0 & 0\end{array}$ $\begin{array}{llllll}0 & 0 & 0 & 0 & 0 & 0\end{array}$ $\begin{array}{llllll}0 & 0 & 0 & 0 & 0 & 0\end{array}$ $\begin{array}{llllll}0 & 0 & 0 & 0 & 0 & 0\end{array}$ $\begin{array}{llllll}0 & 0 & 0 & 0 & 0 & 0\end{array}$ $\begin{array}{llllll}0 & 0 & 0 & 0 & 0 & 0\end{array}$ $\begin{array}{llllll}0 & 0 & 0 & 0 & 0 & 0 \\ 0 & 0 & 0 & 0 & 0 & 0\end{array}$ $\begin{array}{lllll}0 & 0 & 0 & 0 & 0\end{array}$ $\begin{array}{llllll}0 & 0 & 0 & 0 & 0 & 0 \\ 0 & 0 & 0 & 0 & 0 & 0\end{array}$ $\begin{array}{llllll}0 & 0 & 0 & 0 & 0 & 0\end{array}$ $\begin{array}{lllll}0 & 0 & 0 & 0\end{array}$ $\begin{array}{llllll}0 & 1 & 0 & 0 & 0 & 0 \\ 0 & 0 & 0 & 0 & 0 & 0\end{array}$ $\begin{array}{llllll}0 & 0 & 0 & 0 & 0 & 0\end{array}$ $\begin{array}{llllll}0 & 0 & 0 & 0 & 0 & 0\end{array}$ $\begin{array}{llllll}0 & 0 & 0 & 0 & 0 & 0\end{array}$ $\begin{array}{llllll}0 & 0 & 0 & 0 & 0 & 0 \\ 1 & 0 & 1 & 0 & 0 & 0\end{array}$ $\begin{array}{llllll}0 & 0 & 0 & 0 & 0 & 0\end{array}$ $\begin{array}{lllll}0 & 0 & 0 & 0 & 0\end{array}$ $\begin{array}{llllll}0 & 0 & 0 & 0 & 0 & 0 \\ 0 & 0 & 1 & 0 & 0 & 0\end{array}$ \begin{tabular}{lll|lll}
0 & 0 & 1 & 0 & 0 & 0 \\
0 & 0 & 1 & 0 & 0 & 0
\end{tabular} $\begin{array}{llllll}0 & 0 & 0 & 0 & 0 & 0\end{array}$ $\begin{array}{llllll}0 & 0 & 0 & 0 & 0 & 0 \\ 1 & 0 & 1 & 0 & 0 & 0\end{array}$ $\begin{array}{llllll}1 & 0 & 1 & 0 & 0 & 0 \\ 0 & 0 & 0 & 0 & 0 & 0\end{array}$ $\begin{array}{llllll}0 & 0 & 0 & 0 & 0 & 0\end{array}$ $\begin{array}{llllll}0 & 0 & 0 & 0 & 0 & 0\end{array}$ $\begin{array}{llllll}0 & 0 & 0 & 0 & 0 & 0\end{array}$ $\begin{array}{llllll}0 & 0 & 0 & 0 & 0 & 0\end{array}$ $\begin{array}{llllll}0 & 0 & 0 & 0 & 0 & 0\end{array}$ $\begin{array}{llllll}0 & 0 & 0 & 0 & 0 & 0\end{array}$ $\begin{array}{llllll}0 & 0 & 0 & 0 & 0 & 0\end{array}$ $\begin{array}{llllll}0 & 0 & 0 & 0 & 0 & 0\end{array}$ $\begin{array}{llllll}0 & 0 & 0 & 0 & 0 & 0\end{array}$ $\begin{array}{llllll}0 & 0 & 0 & 0 & 0 & 0\end{array}$ $\begin{array}{llllll}0 & 0 & 0 & 0 & 0 & 0\end{array}$ $\begin{array}{llllll}0 & 0 & 0 & 0 & 0 & 0\end{array}$ $\begin{array}{llllll}0 & 0 & 0 & 0 & 0 & 0\end{array}$ \begin{tabular}{llllll}
0 & 0 & 0 & 0 & 0 & 0 \\
0 & 0 & 0 & 0 & 0 & 0 \\
\hline
\end{tabular}

Participant

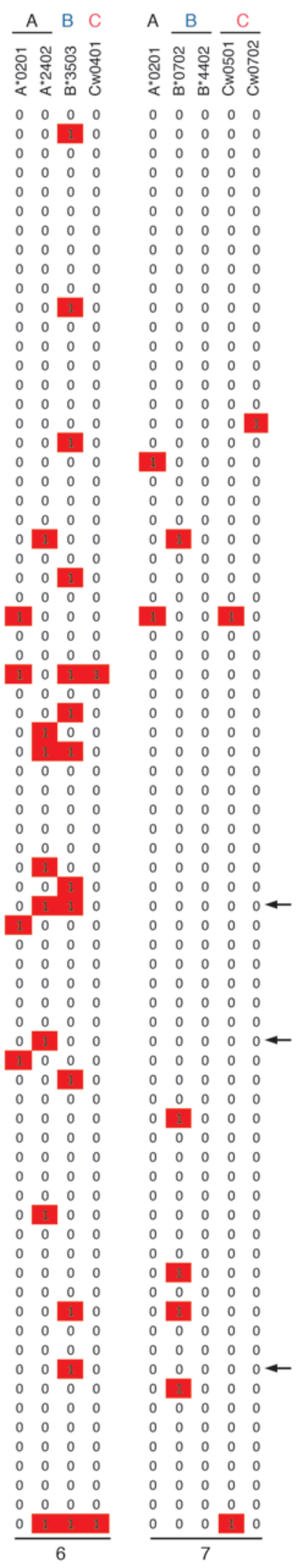

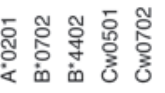

$\begin{array}{lllll}0 & 0 & 0 & 0 & 0\end{array}$ $\begin{array}{lllll}0 & 0 & 0 & 0 & 0\end{array}$ $\begin{array}{lllll}0 & 0 & 0 & 0 & 0\end{array}$ $\begin{array}{lllll}0 & 0 & 0 & 0 & 0\end{array}$ $\begin{array}{lllll}0 & 0 & 0 & 0 & 0\end{array}$ $\begin{array}{llll}0 & 0 & 0 & 0\end{array}$ $\begin{array}{llll}0 & 0 & 0 & 0\end{array}$ $\begin{array}{lllll}0 & 0 & 0 & 0 & 0\end{array}$ 


\section{Figure 6}

HLA allele- and HSV-1 ORF-level IFN- $\gamma$ immune signature of CD8+ cells in PBMCs of 7 individuals infected with HSV-1. Participant identities are listed below the figure. Each column represents an individual HLA-ORFeome screen. The HLA-A, -B, or -C alleles used are indicated at the top. Each row represents the integrated data for an HSV-1 ORF, with ORFs listed in nominal genomic order from RL1 (encoding $\gamma 34.5$ protein) at top to $R S 1$ (encoding protein ICP4) at bottom, with gene names from GenBank NC_001806.1. A red cell shows that specific IFN- $\gamma$ secretion was detected for the intersecting HLA allele and HSV-1 ORF. Data for ORFs expressed as more than one fragment or exon are simplified to a yes/no call. UL36 amino acid coverage was partial (see Discussion). Black arrows indicate, from top to bottom, genes UL39, UL46, and US6.

synthesis prior to DNA replication, or true late with expression only after DNA replication (1). We also recorded, for each HSV-1 protein, its absence, detection at less than $1 \%$, or detection at greater than $1 \%$ of adjusted virion mass using mass spectroscopy data of purified virions (51). These analyses disclosed a weighting of CD8 responses toward HSV-1 proteins expressed prior to HSV-1 DNA replication, and toward abundant virion polypeptides. Specifically, only 3 of 17 true late proteins (18\%) were recognized by $\mathrm{CD}^{+}$cells. In contrast, 4 of 5 immediate early proteins (80\%), 9 of 12 early proteins (75\%), 12 of 19 early late proteins (63\%), 12 of 20 late proteins not specified as early or late (60\%), and 0 of 1 proteins with no specified expression kinetics (0\%) were CD8 antigens (highlighted in Supplemental Figure 5 using Figure 9 data and expression classifications from a standard text; ref. 1). Among the more abundant virion proteins, 17 of 23 (74\%) were positive for CD8 responses. In contrast, only 23 of 51 (45\%) proteins either absent from virions or present at levels less than $1 \%$ were CD 8 antigens. The population prevalence for CD4 responses did not segregate by HSV-1 kinetics or structural class. Our data suggest that whole-virus HSV-1 format vaccines that express most proteins normally made prior to DNA synthesis, or that can be dosed to provide a large mass of virion input proteins, should retain the potential to stimulate broad CD8 responses.

A vaccine covering HSV-1 and HSV-2 would be desirable. Half of the minimal HSV-1 CD8 epitopes defined in this report are sequence-identical in HSV-1 and HSV-2 and appropriate for candidate type-common vaccines. Indeed, the HSV-2 homologs of three epitopes - HLA-A*0101/HSV-1 UL39 512-520, HLAA*0201/HSV-1 UL25 367-375, and HLA-A*0201/HSV-1 UL27 448-456 - were found in our prior HSV-2 work (52-54). HSV CD8 epitopes can also tolerate amino acid substitutions, as exemplified by UL46 354-362 of HSV-1 and HSV-2, differing at amino acid 2, and by ICP0 HSV-1 698-706 and its homolog HSV-2 ICP0 $742-750$, differing at amino acids 1 and 3 . It is certainly possible that cross-reactive $\mathrm{T}$ cells could be involved in cross-protection against some aspects of HSV-2 infection or severity observed in HSV-1-infected individuals (55). Most of our subjects were dually infected with both HSV types. Future cross-sectional studies comparing immune responses to HSV-1 in the presence or absence of HSV-2 coinfection could clarify the extent to which each infection contributes to the cross-reactive repertoire.

With regard to effector function, we showed that bulk HSV-specific $\mathrm{CD}^{+} \mathrm{T}$ cells enriched using cross-presentation and CD137 have brisk virus-specific cytotoxicity. We plan to enrich peptidespecific $\mathrm{CD}^{+}$cells with peptides (56) or tetramers (57) and study recognition of HSV-1-infected skin cells to more closely mimic physiologic target cells. The Cos-7 system has not been characterized for use in CTL assays, so we will move to a viral infection system. In HSV-2 studies, T cells recognizing diverse antigens were able to lyse HSV-infected skin cells, but the specific conditions, such as the dose and time of infection and the requirement for de novo viral protein synthesis or for IFN- $\gamma$ pretreatment $(56,58)$, differed between epitopes. With the larger panel of HSV-1 epitopes, we hope to establish general rules for CD8 recognition of physiologically relevant cells that could inform vaccinology. Future cross-sectional study of populations with defined levels of HSV-1 severity and longitudinal research during the ontogeny of primary

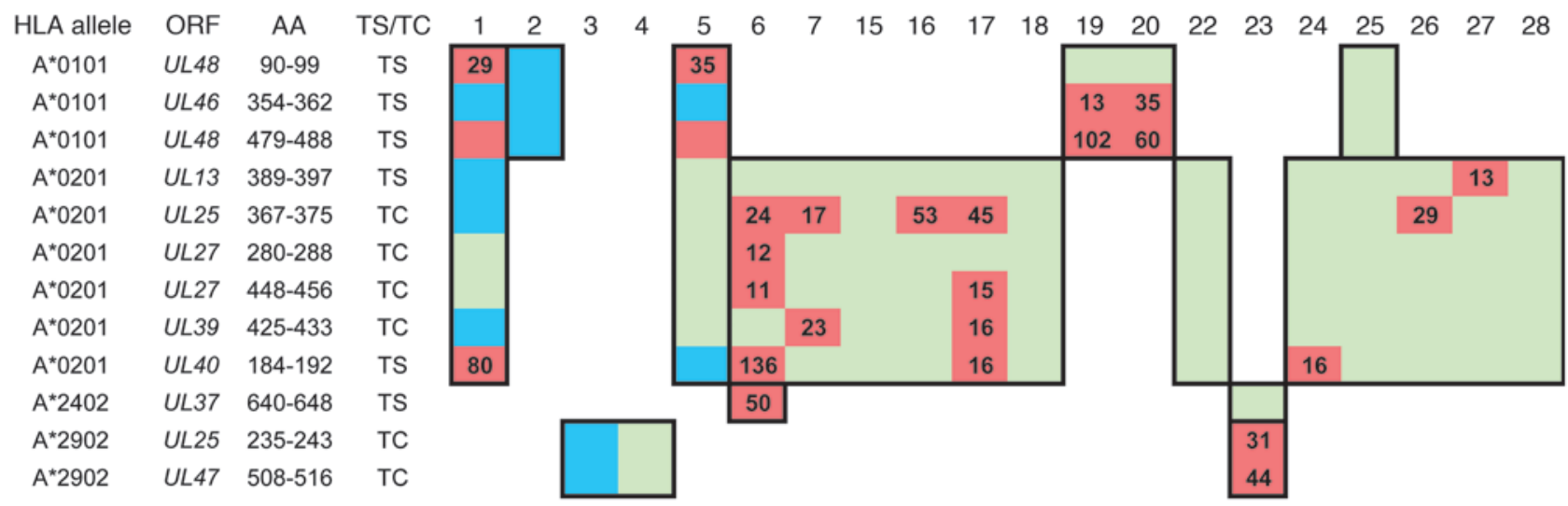

\section{Figure 7}

Graphical summary of direct PBMC IFN- $\gamma$ ELISPOT. HSV-1 peptides from Table 4 ( $n=40$, detailed in Methods) were tested with PBMCs from 20 individuals with HSV-1 infection. Each column represents one participant; $1-7$ are detailed in Table 1. Each row lists a peptide with 1 or more positive ELISPOT results. Green cells represent possible reactivities based on the participant bearing an HLA allele corresponding to the peptide tested, but for which the ORFeome screen with the listed HLA allele and ORF, and peptide ELISPOT, were negative. Blue cells are similar, but the ORFeome screen was positive and the peptide ELISPOT with the indicated peptide was negative. Red cells represent ORFs for which both the ORFeome screen with the listed HLA allele and ORF, and the ELISPOT for at least one peptide in the ORF, were positive. Numbers in red cells are positive ELISPOT results in units of net IFN $\gamma$ SFU $/ 10^{6}$ PBMCs. 
Table 4

HSV-1 CD8 epitopes and HSV-2 homologs

\begin{tabular}{|c|c|c|c|c|c|c|}
\hline HLA allele ${ }^{A}$ & ORFB & $\mathrm{HSV}-1 \mathrm{aa}^{\mathrm{C}}$ & HSV-1 sequence ${ }^{C}$ & HSV-2 sequence ${ }^{D}$ & $\mathrm{HSV}-2 \mathrm{aa}^{\mathrm{D}}$ & $\mathrm{TC} / \mathrm{TS}^{\mathrm{D}}$ \\
\hline$A^{\star} 0101$ & UL1 & $66-74$ & LIDGIFLRY & R-------- & 66-74 & TS \\
\hline$A * 0101$ & UL39 & $512-520^{\mathrm{E}}$ & YMESVFQMY & --------- & $517-525$ & TC \\
\hline$A * 0101$ & UL41 & 259-268 & HTDLHPNNTY & ---------- & $261-270$ & TC \\
\hline$A^{*} 0101$ & UL46 & $354-362^{E}$ & ATDSLNNEY & $-S-------$ & $354-362$ & TS \\
\hline$A * 0101$ & UL47 & $360-368$ & RSSLGSLLY & ---------- & $363-371$ & TC \\
\hline$A * 0101$ & UL47 & $566-574$ & FTAPEVGTY & S-------- & $569-577$ & TS \\
\hline$A^{*} 0101$ & UL48 & 90-99 & SALPTNADLY & $-\mathrm{GF}-----\mathrm{M}-$ & 88-97 & TS \\
\hline$A^{*} 0101$ & UL48 & 479-488 & FTDALGIDEY & $----M---D F$ & $479-488$ & TS \\
\hline$A^{\star} 0101$ & UL53 & $201-209$ & ETDPVTFLY & $-\mathrm{A}-------$ & $201-209$ & TS \\
\hline$A * 0201$ & UL13 & 389-397 & TLLELVVSV & $------\mathrm{L}---$ & 389-397 & TS \\
\hline$A^{*} 0201$ & UL25 & $367-375^{E}$ & FLWEDQTLL & --------- & $372-380$ & TC \\
\hline$A^{*} 0201$ & UL27 & 208-288 & SVYPYDEFV & ---------- & $275-283$ & TC \\
\hline$A * 0201$ & UL27 & $448-456 \mathrm{E}$ & FLIAYQPLL & --------- & $443-451$ & TC \\
\hline$A^{*} 0201$ & UL39 & $425-433$ & RILGVLVHL & --------- & $430-438$ & TC \\
\hline$A^{*} 0201$ & UL40 & $184-192^{F}$ & ILIEGIFFA & $-----V---$ & $181-189$ & TS \\
\hline$A^{*} 0201$ & UL47 & 286-294 & FLADAVVRL & $--V--I--V$ & 289-297 & TS \\
\hline$A^{\star} 0201$ & UL47 & $374-382$ & ALLDRDCRV & $---\mathrm{G}-----$ & $377-385$ & TS \\
\hline$A^{*} 0201$ & UL47 & $545-553$ & RLLGFADTV & $----\mathrm{L}----$ & $548-556$ & TS \\
\hline$A * 2402$ & UL21 & $162-170^{F}$ & VYTPSPYVF & A--------- & $162-170$ & TS \\
\hline$A * 2402$ & UL31 & $292-300$ & EYQRLYATF & --------- & 291-299 & TC \\
\hline$A * 2402$ & UL37 & $221-230$ & AYSLLFPAPF & $-------S-I$ & $221-230$ & TS \\
\hline$A * 2402$ & UL37 & $640-648$ & AYLPRPVEF & $------I--$ & $640-648$ & TS \\
\hline$A * 2402$ & UL46 & $226-234$ & AYVSVLYRW & $-------H-$ & $226-234$ & TS \\
\hline$A * 2402$ & UL54 & $504-512$ & KYFYCNSLF & --------- & 504-512 & TC \\
\hline$A * 2402$ & ICP4 & $1097-1106$ & LYPDAPPLRL & PDG-----V- & $1243-1252$ & TS \\
\hline$A * 2902$ & UL25 & $170-179$ & SSGVVFGTWY & ---------- & $175-184$ & $\mathrm{TC}$ \\
\hline$A * 2902$ & UL25 & $235-243$ & AVLCLYLLY & --------- & $240-249$ & TC \\
\hline$A * 2902$ & UL26 & $22-30$ & YVAGFLALY & ---------- & $22-30$ & TC \\
\hline$A^{*} 2902$ & UL26 & $326-334^{F}$ & YLWIPASHY & --------- & $328-336$ & TC \\
\hline$A^{*} 2902$ & UL27 & 295-303 & VYMSPFYGY & --------- & 290-298 & $\mathrm{TC}$ \\
\hline$A * 2902$ & UL27 & $641-649$ & FTFGGGYVY & $-I-------$ & $638-646$ & TS \\
\hline$A^{*} 2902$ & UL29 & $460-468$ & ALLAKMLFY & --------- & $460-468$ & TC \\
\hline$A * 2902$ & UL29 & $895-903^{F}$ & YMANQILRY & --------- & $895-903$ & TC \\
\hline$A * 2902$ & UL46 & $93-101$ & LASDPHYEY & $-------D-$ & 93-101 & TS \\
\hline$A * 2902$ & UL46 & $126-134$ & AILTQYWKY & $---A-----$ & $126-134$ & TS \\
\hline$A * 2902$ & UL46 & $224-232$ & LLAYVSVLY & --------- & $224-234$ & $\mathrm{TC}$ \\
\hline$A * 2902$ & UL46 & $333-341$ & SIVHHHAQY & --------- & $333-341$ & $\mathrm{TC}$ \\
\hline$A * 2902$ & UL47 & $508-516^{\mathrm{F}}$ & ALATVTLKY & --------- & $511-519$ & TC \\
\hline $\mathrm{B}^{\star} 0702$ & ICPO & $698-706^{E}$ & VPGWSRRTL & $\mathrm{A}-\mathrm{A}------$ & $742-750$ & TS \\
\hline$B \star 0702$ & UL21 & $382-390$ & VPRPDDPVL & $--\mathrm{A}--\mathrm{E}-\mathrm{T}-$ & $380-388$ & TS \\
\hline$B \star 0702$ & UL49 & $281-290$ & RPTERPRAPA & $--\mathrm{AG}-\mathrm{AA}-\mathrm{T}-$ & $276-285$ & TS \\
\hline $\mathrm{B}^{\star} 0702$ & US1 & $70-78$ & APRIGGRRA & GDLR----R & $62-70$ & TS \\
\hline $\mathrm{B}^{\star} 0702$ & US7 & $22-30$ & VVRGPTVSL & --------- & $22-30$ & $\mathrm{TC}$ \\
\hline$B \star 0702$ & US7 & $97-105$ & CPRRPAVAF & ---------- & $97-105$ & TC \\
\hline $\mathrm{B}^{\star} 0702$ & US7 & $195-203$ & APASVYQPA & $\mathrm{G}-\mathrm{S}---\mathrm{T}-\mathrm{G}$ & 195-203 & TS \\
\hline
\end{tabular}

Polyclonal responder cells derived by cross-presentation and positive when screened with the indicated HLA alleles and ORFs were reactive with the indicated HSV-1 peptides. AHLA cDNA used to screen HSV-1 ORFeome clone set. ${ }^{B} \mathrm{HSV}-1$ ORF scoring positive that yielded a reactive peptide. ${ }^{\mathrm{C}}$ Amino acid numbers and HSV-1 sequences from GenBank NC_001806.1 scoring positive in IFN- $\gamma$ ICC assay. DPredicted aa sequence and homologous portion of corresponding HSV-2 protein from GenBank NC_001798.1 (HSV-2). TC, type common epitope, identical between HSV-1 and HSV-2; TS, type specific. EThe HSV-2 homologs of these epitopes were previously described as CD8 epitopes with the same proven or probable HLA restriction using PBMCs from HSV-2-infected individuals and HSV-2 peptides (52-54). In the case of ICPO 742-750 of HSV-2, the epitope was previously assigned amino acids 743-751 (93) based on our finding of an extra aa at the exon 1-exon 2 splice junction, based on cDNA sequencing, that is not present in GenBank NC_001798.1. FMultiple synthetic peptides were positive. For HLA-A*0201/UL40, 9-mer 184-192 and 10-mers 184-193 and 183-192 were positive. Similarly, for HLA-A*2902/UL26, 10-mer 325-334 and 9-mer 326-334 were positive; for HLA-A*2902/UL29, 10-mer 894-903 and 9-mer 895-903 were positive; for HLA-A*2902/UL47, 10-mer 508-517 and 9-mer 508-516 were positive; and for HLA-A*2402/UL21, 10-mer 161-170 and 9-mer 162-170 were positive (Supplemental Figure 4; active 9-mers are shown, but the 10-mers are similar). 
A

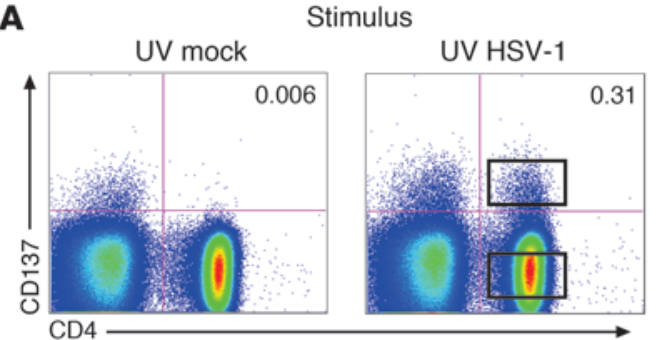

$\mathrm{CD} 137^{\mathrm{hi}}$
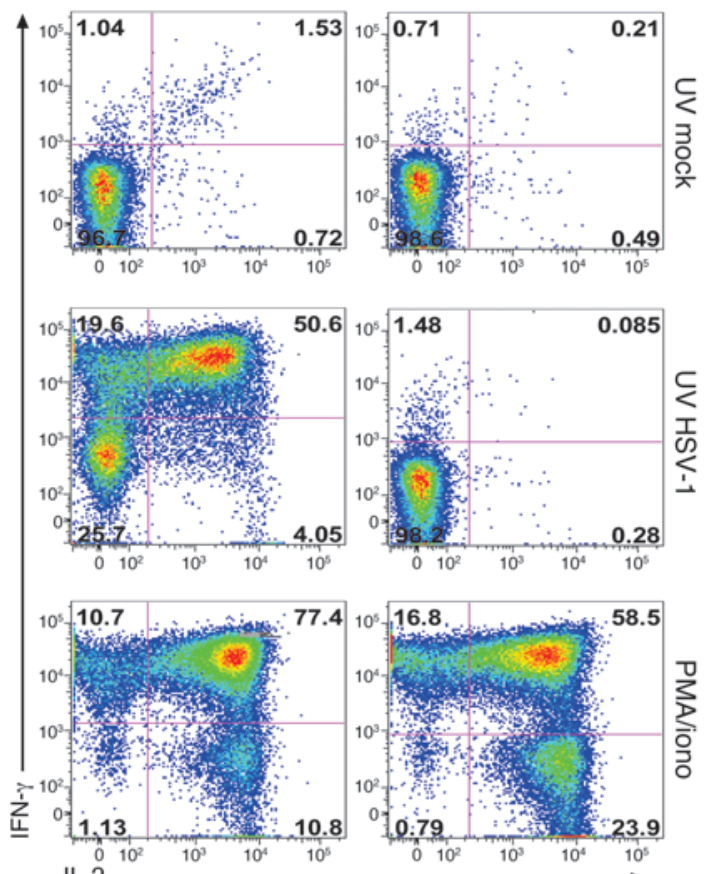

\section{CD137}

$$
\text { IL-2 }
$$

\section{Figure 8}

Use of CD137 expression to enrich HSV-1-specific $\mathrm{CD} 4^{+} \mathrm{T}$ cells, and representative raw data from HSV-1 proteome-wide scan. (A) Top 2 panels show expression of CD137 by PBMCs after 20 hours of exposure to whole cell-associated UV-killed mock or HSV-1 lysate. Dot plots were gated for live, $\mathrm{CD}^{+}$ cells in the lymphocyte forward/side scatter region. Numbers are percentages of cells in the upper-right quadrant. Small boxes indicate approximate gates for FACS. Bottom 6 panels show reactivity of polyclonal twice-expanded responder cell lines derived from $\mathrm{CD}^{+}{ }^{+} \mathrm{CD} 4{ }^{+} \mathrm{CD} 137^{\text {hi }}$ or $\mathrm{CD} 3^{+} \mathrm{CD} 4{ }^{+} \mathrm{CD} 137^{10}$ cells, after 18 hours reexposure to autologous APCs and whole cell-associated UV-killed mock or HSV-1 lysate. APCs were CFSE dump-gated and responder cells stained intracellularly for IFN- $\gamma$ and IL-2. Numbers are percentages of cells in indicated quadrants. (B) Representative screen of polyclonal HSV-1-reactive $\mathrm{CD}^{+}$cells to each HSV-1 protein or fragment, whole HSV-1-positive control, and irrelevant microbial negative control proteins. Data are mean of duplicate assays. Red line is cutoff for positive responses calculated as described in Methods.

B

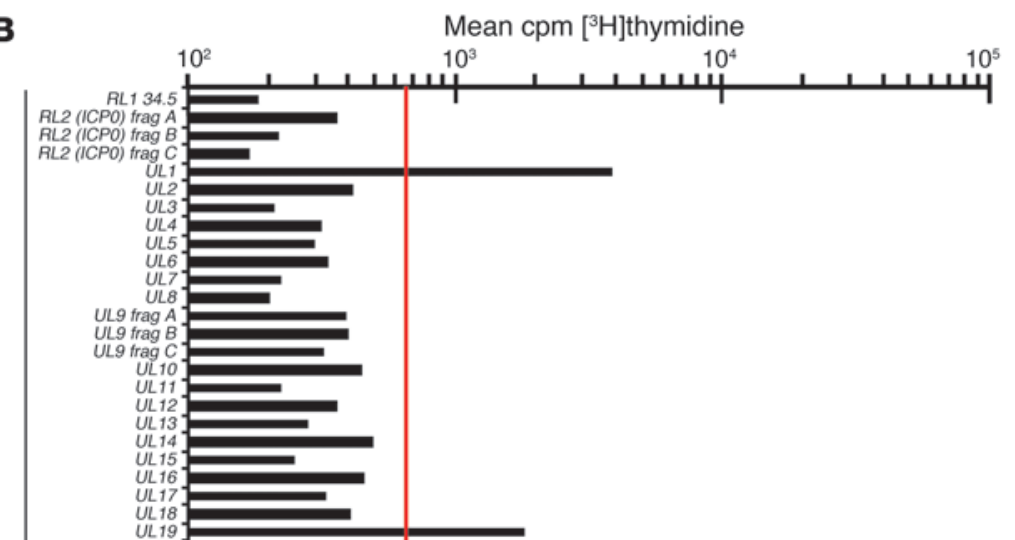




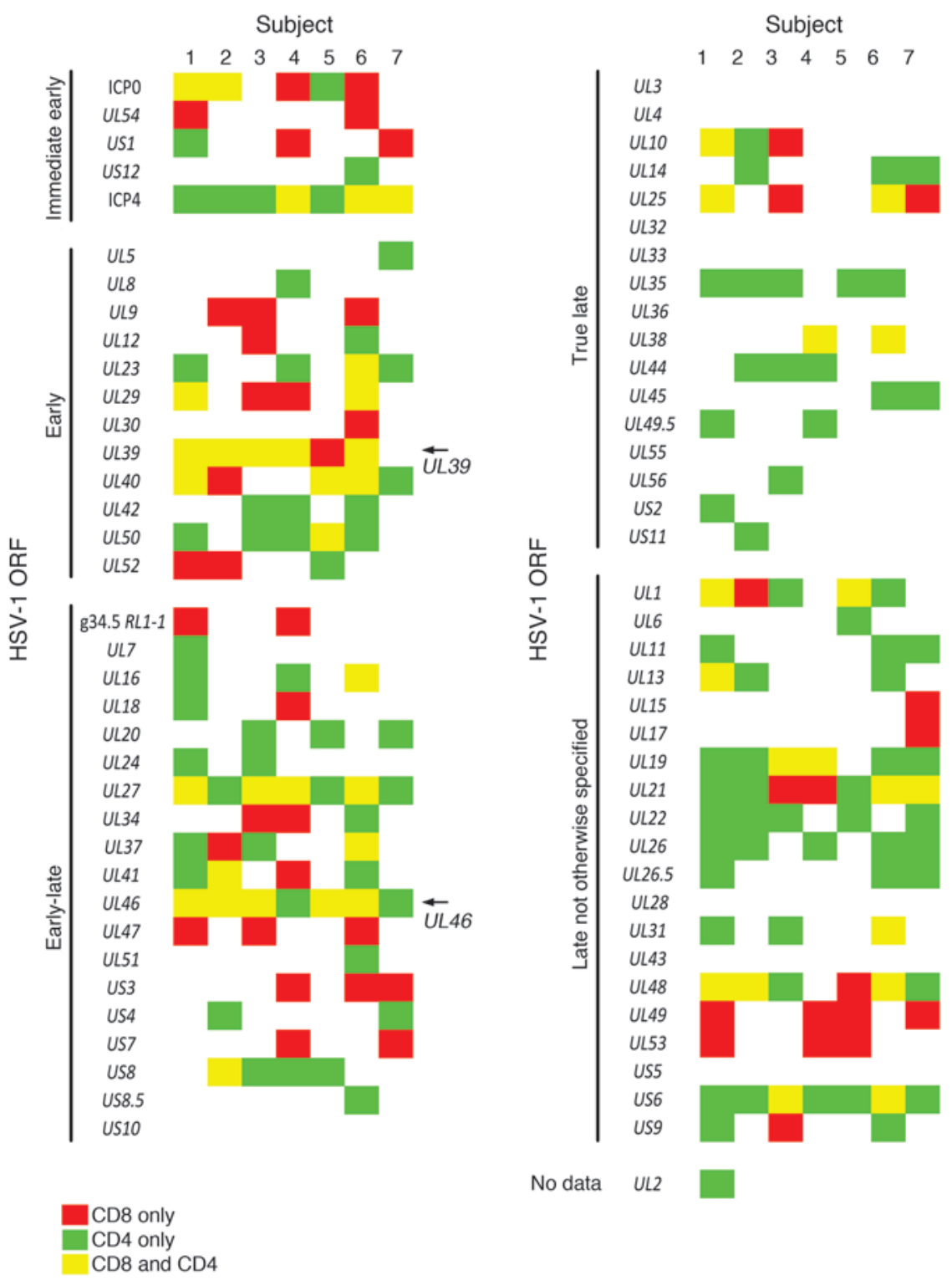

\section{Figure 9}

Graphical representation of CD4 and CD8 reactivity to HSV-1 ORFs in PBMCs from 7 HSV-1-infected individuals, indicated in the rows. Each column is an HSV-1 ORF. The ORFs are grouped by their kinetic expression during viral replication. White indicates no reactivity.

counterpoint to the powerful manipulative experiments that are possible in experiment models of HSV-1 infection.

Several factors may have influenced our results. Our CD8 workflow used cross-presentation at the re-stimulation step, but then switched to direct present by aAPCs or peptide-loaded cells at the readout step. We observed that cross-presentation is efficient in presenting diverse HSV-1 proteins to $\mathrm{CD}^{+} \mathrm{T}$ cells. The HSV proteins ICP47 (gene US12) and vhs (gene UL41) inhibit direct presentation (30). We have previously restimulated memory $\mathrm{CD}^{+}$cells using direct presentation by HSV-infected B lymphoblastoid cell lines (B-LCLs), but this yielded a paucity of HSV-reactive CD8 clones reactive only with membrane glycoproteins (62). HSV-infected fibroblasts failed in this endeavor. Direct presentation by infected DCs might uncover epitopes specific for this pathway, although HSV infection harms various DCs and renders them defective for antigen presentation (63-65). Future studies will compare direct and cross-presentation at the re-stimulation stage.

Expression of the HSV-1 proteome was not totally complete. Genes UL15.5, UL20.5, UL27.5, and UL43.5 are under development, as is the C-terminal approximately 500 amino acids of the UL36 protein. Genes predicted to be in-frame

immune responses or during reactivations in the chronic phase may also contribute correlates of severity and reactivation that could further influence vaccine design.

Interestingly, UL39 was a strong HSV-1 CD8 antigen in both humans and the one mouse MHC haplotype studied, H-2 ${ }^{\text {b }}$. UL39 is a virulence factor involved in evading innate immunity and apoptosis (59), such that immune targeting of UL39 may be advantageous to the host. The CD8 repertoire in infected C57BL/6 mice had a breadth of $19 \mathrm{HSV}-1$ epitopes. These were concentrated in only three ORFs, gB1 (gene UL27), UL39, and ICP8 (gene UL29) (60). The mice did not recognize immediate early HSV-1 polypeptides, while responses to ICP0, ICP4, ICP22, and ICP47 were detected in humans. In addition to MHC class I peptide binding preferences, these differences may reflect species-specific effects of HSV-1 HLA class I immune evasion genes (61) and the fact that the human exposure to HSV-1 antigen is chronic and intermittent, while HSV-1 typically does not recur in mice. We conclude that study of adaptive immunity in the natural host is a necessary subsets of longer polypeptides were not included, but this will not lead to loss of potential epitopes. A poorly studied variable is allelic heterogeneity in HLA class I assembly with Chlorocebus sp. $\beta 2 \mathrm{~m}$ in Cos-7 cells. We overexpressed HSV-1 ORFs in isolation in aAPCs, where intracellular trafficking and class I presentation could differ from the viral context. There were subtle differences in some of our HLA-C constructs from the HLA-A and -B vectors, but our method has achieved excellent HLA-C expression (66). There are interactions between HSV-1 proteins such as proteolysis and phosphorylation (1), and possibly species-specific host protein-HSV-1 protein interactions, that would differ between infected and transfected cells. In HSV-2 work using a genomic DNA library and Cos-7 transfection, we decoded the fine specificity of each CD8 clone studied $(52,56,67)$ and therefore believe such situations are rare for HSV. We focused on IFN- $\gamma$ readouts of $\mathrm{CD}^{+} \mathrm{T}$ cell activation and proliferation to detect $\mathrm{CD}^{+} \mathrm{T}$ cell responses. With regard to effector cytokines, rare HSV-reactive T cells in PBMCs making TNF- $\alpha$ or IL- 2 but not IFN- $\gamma$ have been 
A

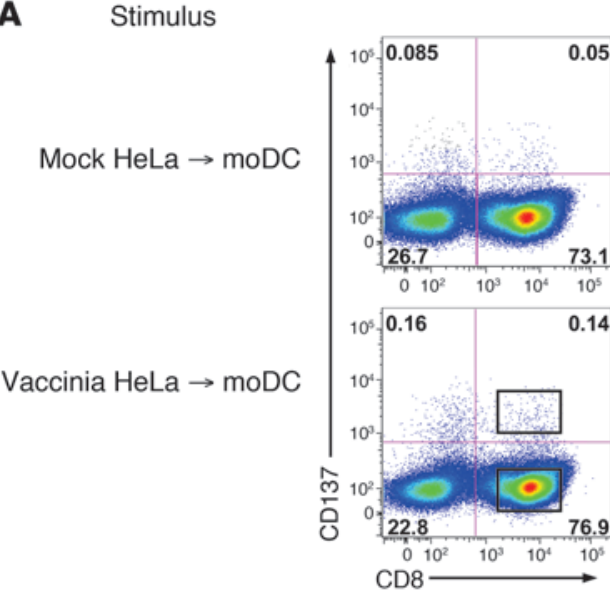

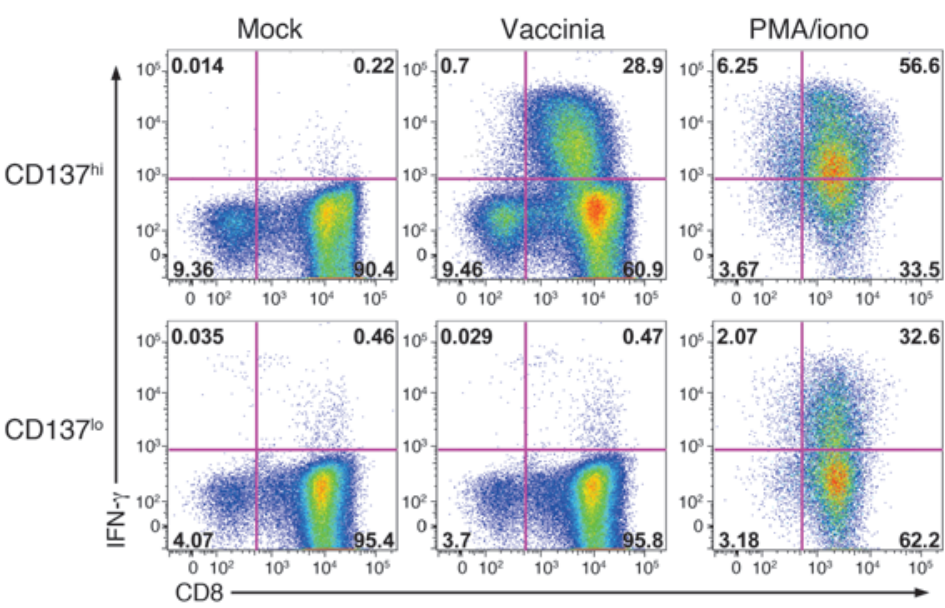

B

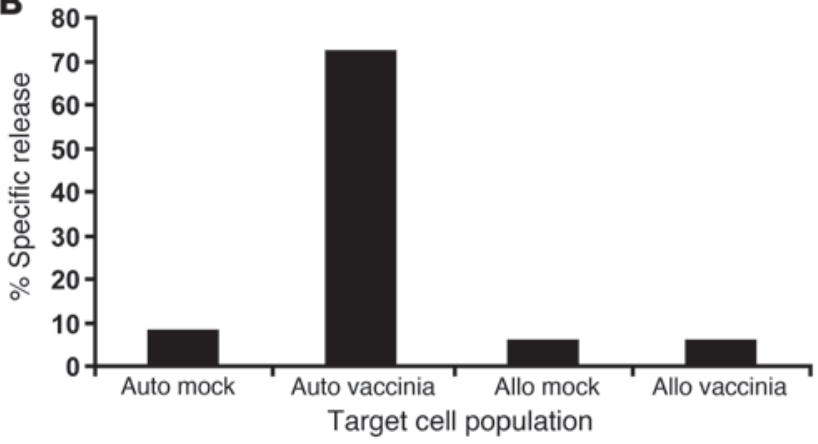

C Stimulus
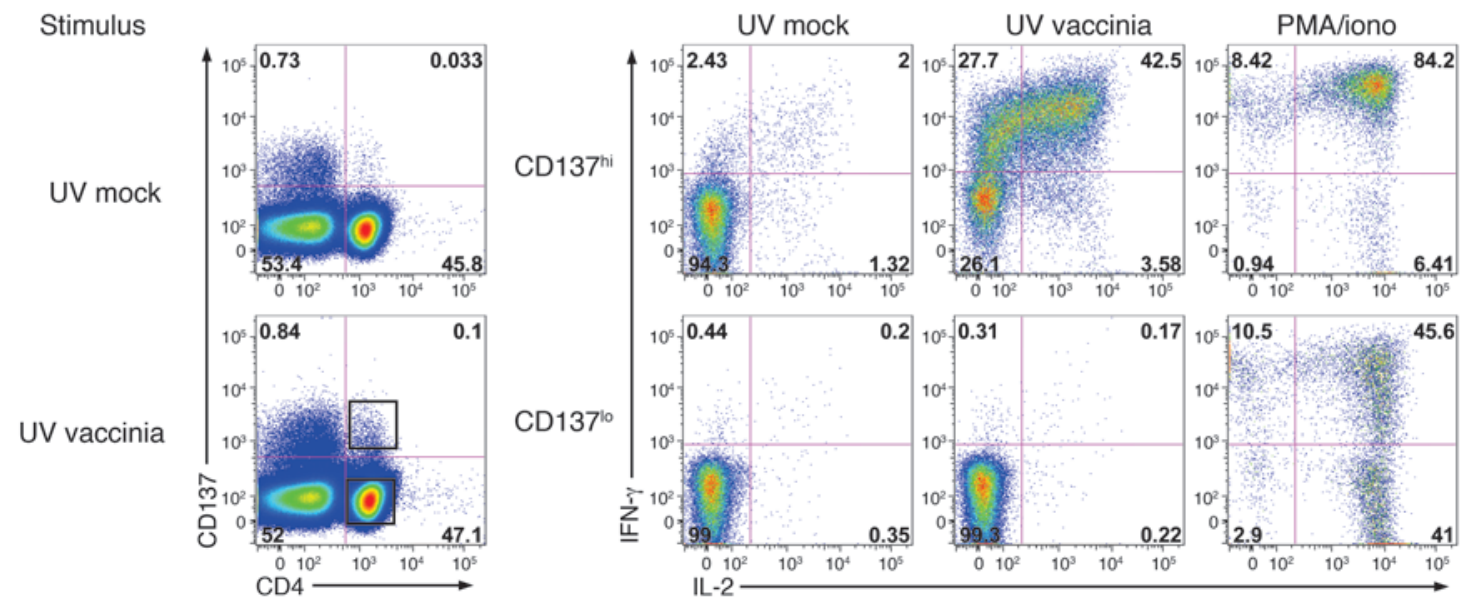

Figure 10

Detection and enrichment of vaccinia-specific CD8 ${ }^{+}$and CD4+ $\mathrm{T}$ cells. (A) Left panels show expression of CD137 after 20 hours of exposure of CD8 ${ }^{+}$T cells to cross-presented mock or vaccinia antigen. Small boxes indicate approximate gates for FACS. Numbers are percent of total gated live $\mathrm{CD}^{+}$lymphocytes in each quadrant. Right panels show IFN- $\gamma$ expression by bulk, expanded CD8 ${ }^{+}$CD137 hi or CD137lo cells in response to exposure to autologous B-LCLs in the absence or presence of vaccinia infection, or positive control stimulus. Numbers are percentages of gated live, $C D 3^{+}$lymphocytes in each quadrant. (B) Cytolytic activity of bulk, expanded CD8 ${ }^{+}$CD 137 hi cells to autologous or allogeneic APCs with or without vaccinia infection. (C) Left panels show expression of CD137 by CD4+ T cells after 20 hours of exposure of PBMCs to UV-inactivated, cell-associated mock or vaccinia antigen. Small boxes indicate approximate gates for FACS. Numbers are percentages of gated live, CD3+ lymphocytes in each quadrant. Right panels show IFN- $\gamma$ and IL-2 expression of polyclonal expanded CD4+ CD137hi or CD137lo cells to autologous APCs and mock or vaccinia antigen. APCs were CFSE dump-gated. Numbers are percentages of live, CD4+ cells in each quadrant.

described (54). In preliminary studies, substitution of TNF- $\alpha$ for IFN- $\gamma$ ELISA did not uncover additional specificities (data not shown). We noted one HSV-seronegative individual with CD8 responses to HSV-1 (participant 13 in Table 2). Further work will be required to determine whether reactivity can be confirmed at the epitope level, as has been done for HSV-2 (68).

We have extended the use of CD137 as an activation marker to two complex microbes for both $\mathrm{CD}^{+}$and $\mathrm{CD}^{+} \mathrm{T}$ cells. CD137 


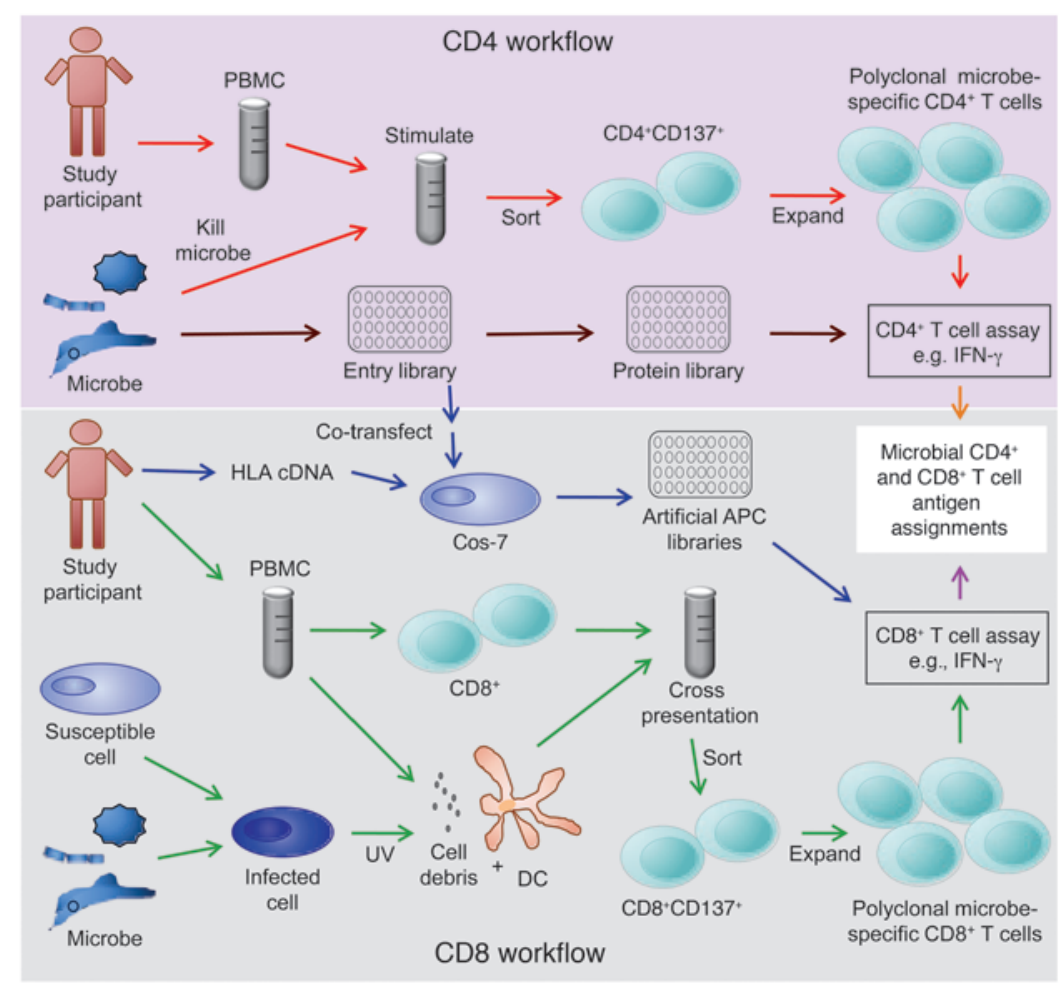

\section{Figure 11}

Schematic overview of the high-throughput T cell antigen discovery pathway. See text for details. In this report, the microbe (left) was a virus, HSV-1, but the workflow can also be adapted to bacteria or parasites. A microbial ORF library is initially cloned in a flexible format and subcloned (not shown) into both a custom protein expression vector for CD4 assays and a custom transient expression vector for CD8 assays. The CD4 workflow (top) stimulates PBMCs with whole killed microbe and detects and isolates microbespecific CD4+ $\mathrm{T}$ cells based on differential CD137 expression followed by expansion. The polyclonal $\mathrm{CD}^{+}{ }^{+}$responder cells are then assayed against the protein library made in vitro from the secondary protein expression clone set. The CD8 workflow (bottom) uses cross-presentation by microbial antigen-laden $\mathrm{DCs}$ to stimulate CD8 ${ }^{+} \mathrm{T}$ cells from PBMCs. After CD137-based selection and expansion, effector cells are assayed for reactivity with panels of person-specific aAPCs made by co-transfection of Cos7 cells with participant HLA class I cDNA and the transient transfection microbial ORF set. The integrated assays assign each ORF a yes/no result for each participant for $\mathrm{CD}^{+}$and $\mathrm{CD} 8{ }^{+} \mathrm{T}$ cells (turquoise). mediates a strong co-stimulatory signal to T cells. Thus, use of anti-CD137 to detect and purify antigen-reactive cells may assist their downstream expansion. Our data are consistent with some level of bystander CD137 expression, as the level of reactivity with whole HSV-1 among expanded CD137hi cells varied between 4\% and $45 \%$. Enrichment was better for CD 4 cells. We cannot be sure that all memory HSV-reactive cells upregulated CD137. CD137 is similar in this regard to other molecules used for enrichment, such as CD134, CD154, and captured IFN- $\gamma$ (69).

In summary, the $\mathrm{T}$ cell response to a complex and serious pathogen with a large genome, HSV-1, has been decoded with a linked set of cellular and molecular tools to reveal novel candidate vaccine antigens. We have preliminarily identified the proteins encoded by genes UL39 and UL46 as having high population prevalence of coordinated CD8 and CD4 responses and plan to study larger, defined populations to refine these conclusions. Cross-presentation followed by CD137-based selection also effectively enriches rare $\mathrm{CD}^{+}$cells specific for vaccinia virus, an effective live virus vaccine. $\mathrm{CD} 137$ is also suitable for enrichment of $\mathrm{CD}^{+} \mathrm{T}$ cells reactive with whole microbe preparations, as demonstrated for both HSV-1 and vaccinia virus. Our flexible gene cloning format allows integrated, efficient study of both CD8 and CD4 responses after one round of PCR-based cloning of microbial ORFs. Use of appropriate initial re-stimulation conditions, CD137 as a flexible selection marker, and the genomes and complete genome-covering ORF sets now available for Mycobacterium tuberculosis, Plasmodium falciparum, and other agents should speed comprehensive definition of $\mathrm{T}$ cell responses and vaccine design.

\section{Methods}

Participants and specimens. Healthy adults with HSV-1 infection were recruited at the University of Washington Virology Research Clinic. Participants were antibody negative for HIV-1. HSV-1 and HSV-2 infections were documented with type-specific serum immunoblot (70). Vaccinia immune status was derived from history of vaccinia vaccination. None of the participants had an oral or genital recurrence or received anti- herpesviral medication at the time of lymphocyte collection. The collection of PBMCs from vaccinia-immune individuals has been documented (71). Peripheral venous blood was collected with heparin and processed by Ficoll density gradient centrifugation (72). A 150-ml blood sample allowed CD8 and CD4 analyses for HSV-1. PBMCs were cryopreserved until use.

HLA typing. HLA at A and B loci was typed at the Puget Sound Blood Center, Seattle, Washington. When 2 digits followed by $\mathrm{xx}$ or 4 digits are reported, low or high resolution typing was done and the old nomenclature used (73). HLA-C was typed by Dan Geraghty at the Fred Hutchinson Cancer Research Center by sequencing exons 2 and 3. Ambiguous HLA-C alleles are reported to 4 digits (predicted amino acid sequence) using the older nomenclature if there are only two possibilities. Some HLA-C alleles are reported using the new G nomenclature (http://hla. alleles.org/alleles/g_groups.html) when there are multiple possible amino acid sequences (73).

Virus and cell culture. HSV-1 strain E115 (74) and HSV-2 strain 333 (75) were grown and titered (62) on Vero cells (ATCC). Vaccinia strain WR was grown and titered as described previously (76). Viral antigens for $\mathrm{CD}^{+}$cell stimulation and readout assays were diluted sonicates of Vero (HSV-1) or BSC40 (vaccinia) harvested by scraping when $80 \%-100 \%$ of the monolayer showed cytopathic effect and treated with UV light to eliminate infectious virus $(72,77)$. HeLa and Cos-7 cells (ATCC) were cultured in DMEM. B-LCLs were immortalized from PBMCs using EBV strain B95-8 (62) and are permissive for HSV infection (78). Continuous cell lines were Mycoplasma negative (Lonza). moDCs were cultured from adherent or CD14 positively selected (Miltenyi) PBMCs using media, conditions, and recombinant human GM-CSF and IL-4 as described previously (53). Media (72, 79) used 10\% Fetalclone III (Fisher) instead of FCS. 
Enrichment and expansion of virus-reactive T cells from PBMCs. For HSV-1specific $\mathrm{CD}^{+} \mathrm{T}$ cell enrichment, HeLa cells, seeded 1-2 days previously in 6 -well plates at $3 \times 10^{5}$ cells/well and used at $80 \%-90 \%$ confluence, were infected with HSV-1 at an MOI of 5, or a similar dilution of mock virus, for 30 minutes with rocking in serum-free medium at $37^{\circ} \mathrm{C}, 5 \% \mathrm{CO}_{2}$, followed by addition of complete medium. At 18 hours, a cytopathic effect was visible by microscopy. Cells were recovered by $20 \mathrm{mM}$ EDTA and scraping, washed in TCM, resuspended at $2 \times 10^{6} / \mathrm{ml}$ in TCM, plated in a 6 -well plate, and exposed to UV radiation (Stratalinker XL1000, Agilent, 180,000 microjoules). moDCs were similarly recovered from their culture wells, washed, and resuspended at $2 \times 10^{6} / \mathrm{ml}$ in TCM and plated at $100 \mu \mathrm{l} /$ well in 48 -well plates. HeLa debris $\left(100 \mu \mathrm{l} /\right.$ well, equivalent to $2 \times 10^{5}$ cells/well prior to UV) was added for a moDC/HeLa ratio of $1: 1$ for 5 hours at $37^{\circ} \mathrm{C}$, $5 \% \mathrm{CO}_{2}$. $\mathrm{CD}^{+} \mathrm{T}$ cells were negatively selected from autologous PBMCs (Miltenyi) and added $\left(1 \times 10^{6} /\right.$ well in $\left.300 \mu \mathrm{l}\right)$ to the antigen-loaded moDCs for a responder/DC ratio of 10:1 in a final volume of $500 \mu \mathrm{l} \mathrm{TCM} /$ well. Antigen loading and stimulations typically involved 15-20 identical wells/ person. Vaccinia-specific $\mathrm{CD}^{+} \mathrm{T}$ cells were restimulated by cross-presentation as described for $\mathrm{T}$ cell clones (80), except that bulk PBMC-derived $\mathrm{CD}^{+} \mathrm{T}$ cells were used as responders. The remainder of the procedure matched that for HSV-1.

Stimulation was for 20 hours at $37^{\circ} \mathrm{C}, 5 \% \mathrm{CO}_{2}$. Cells were pooled and stained with 7-AAD, anti-CD3-PE, anti-CD8 $\alpha$-FITC, and anti-CD137allophycocyanin (BD) for 30 minutes at room temperature in $50 \mu \mathrm{l} \mathrm{TCM}$. After 2 washes, cells were resuspended in $1 \times 10^{7} / \mathrm{ml}$ in TCM. FACSAria II (BD) FACS used initial gating of live $\mathrm{CD}^{+}$lymphocytes. All available $\mathrm{CD} 8^{+}$ CD137hi cells were collected, as was a fraction of the abundant CD137negative cells. Sorted cells were washed and plated in bulk with $1.5 \times 10^{5}$ allogeneic 3,300 rad-irradiated PBMCs and $1.6 \mu \mathrm{g} / \mathrm{ml}$ PHA-P (Remel) in $200 \mu \mathrm{l} \mathrm{TCM}$ in a 96-well U-bottom plate. Natural hIL-2 (32 U/ml, Hemagen) was added on day 2 and maintained for 14-16 days, typically yielding $1 \times 10^{6}$ to $10 \times 10^{6}$ cells. A portion of the output cells from the first expansion were bulk stimulated with anti-CD3 $\mathrm{mAb}$, feeder cells, and recombinant hIL-2 (79). This typically yielded a 1,000-fold cell increase in 14 days (81). Frozen sister aliquots of expanded cells were thawed for downstream assays. Reexpansion was not required.

Enrichment of virus-specific $\mathrm{CD} 4^{+} \mathrm{T}$ cells began with addition of UVinactivated, cell-associated HSV-1 or vaccinia (MOI of 1 prior to inactivation) to $2 \times 10^{6}$ PBMCs per well of 24 -well plates in $2 \mathrm{ml} \mathrm{TCM}$. This HSV preparation has been proven to contain nonstructural proteins such as the UL50-encoded enzyme, and structural proteins (82). Cultures were initiated from $15 \times 10^{6}$ to $20 \times 10^{6}$ PBMCs. After 20 hours, cells were stained as above, but anti-CD4 was substituted for anti-CD8 $\alpha$. Live $\mathrm{CD}^{+}{ }^{+} \mathrm{CD} 4{ }^{+} \mathrm{CD} 137^{+}$cells, and a portion of the $\mathrm{CD} 3{ }^{+} \mathrm{CD} 4{ }^{+} \mathrm{CD} 137-$ cells, were sorted and expanded in bulk as above.

HSV-1 ORFeome. Total DNA was prepared from cells infected with HSV-1 strain $17+(14)$ using the QIamp DNA Blood Mini Kit (QIAGEN) using the cultured cell instructions. PCR primers were designed (Supplemental Table 1) to amplify each annotated ORF in HSV-1 (GenBank NC_001806). Whenever possible, full-length ORFs were amplified. For ICP0, each exon was amplified independently. Since UL15 has an intron, its entry vector was generated using a cDNA clone as PCR template. Nomenclature was from a standard reference (1). In some cases, long ORFs were amplified as fragments, usually overlapping by several amino acids (Supplemental Table 1). These were labeled as fragment A (frag A), etc., in the $\mathrm{N}$ - to C-terminal direction. In other cases, both a full-length clone and an internal fragment or fragments were separately cloned; the first internal fragment is labeled as frag $\mathrm{A}$ if it starts near the $\mathrm{N}$ terminus and frag $\mathrm{B}$ if not. ORFs that are internal to, in-frame with, and therefore have polypeptide sequences identical to fragments of longer ORFs, such as ORF UL26.5 within UL26 (1), were separately cloned in some instances but are not separately reported (see below). For each gene or fragment, both primers had a 5 ' extension to allow recombinase-mediated integration into pDONR207 or pDONR221 (Invitrogen), yielding vectors termed pENTR207-gene X or pENTR221gene $\mathrm{X}$. Invitrogen reagents were used for recombination. Plasmids recovered from candidate bacterial colonies were evaluated by restriction endonucleases and/or sequencing.

Vector pDEST103, for CD8 work, accepts DNA inserts from either pDONR207 or pDONR221, and expresses polypeptides of interest such that EGFP is at the $\mathrm{N}$ terminus of a fusion polypeptide. To create pDEST103, peGFP-C1 (Clontech) was linearized with XhoI, blunt-ended with T4 DNA polymerase and dNTPS, dephosphorylated with calf intestinal alkaline phosphatase, and gel-purified. Reading frame cassette A (Invitrogen) was ligated with T4 DNA ligase into peGFP-C1. After selection with chloramphenicol and kanamycin in E. coli strain $c c d B$ survival $2 \mathrm{~T} 1^{\mathrm{R}}$, intermediary vector pDEST102 was recovered, and the orientation of the cassette was confirmed by sequencing. pcDNA3.1(+) (Invitrogen) was digested with NheI and HindIII. pDEST102 was similarly digested, and the insert, comprising EGFP and cassette A with termini, was gel purified and ligated into digested pcDNA3.1(+), creating pDEST103. pDEST103 expressed the $c c d B$-encoded protein and was selected with ampicillin and chloramphenicol in $c c d B$ survival $E$. coli. The identity of pDEST103 was confirmed by sequencing through att recombination sites, EGFP, and flanking regulatory regions. HSV-1 inserts were transferred from either of the pENTR series vectors (above) to pDEST103 with LR Clonase II (Invitrogen) and selected using ampicillin in E. coli DH5 $\alpha$, yielding pEXP103-gene X vectors. Candidate pEXP103-gene X expressing HSV-1 polypeptides were sequenced through their EGFP-HSV junctions at the N termini of the HSV polypeptide, and through the $\mathrm{C}$ termini insert-vector junctions. The fusion polypeptides are predicted to encode EGFP, followed by peptide SGLRCRITSLYKKAGF, followed by the HSV-1 polypeptide of interest. DNA was prepared using anion exchange (QIAGEN), measured at $\mathrm{OD}_{260}$ (Nanodrop), and diluted in water $(100 \mathrm{ng} / \mu \mathrm{l})$ for transfection.

Expression of each HSV-1 ORF was checked by transfection of Cos-7 cells cultured in 96-well flat-bottom plates as described previously (81) with 100 $\mathrm{ng} /$ well DNA. Forty-eight hours later, cells recovered by trypsinization were stained with Violet LIVE/DEAD (Invitrogen) and were analyzed for EGFP by flow cytometry after gating on live cells. For protein gD1, pEXP103-US6 expression was confirmed with a $\mathrm{mAb}$ and flow cytometry as described previously (83). For protein gB1, pEXP103-UL27 expression was confirmed using the same technology, except that mAb H1817 (Novus) was used at $5 \mu \mathrm{l} /$ tube as the primary antibody and PE-conjugated goat anti-mouse IgG (Invitrogen) was used at $1 \mu \mathrm{l} /$ tube as secondary antibody.

Each predicted HSV-1 polypeptide from the pENTR series (above) was separately subcloned into custom vector pDEST203 designed for in vitro protein expression and CD4 research. For construction of pDEST203, pIVEX2.4d (Roche) was digested with XhoI, blunt-ended with T4 DNA polymerase and dNTPs, dephosphorylated, and ligated with the reading frame B cassette (Invitrogen). Colonies were selected in $c c d B$ survival E. coli as above but with ampicillin and chloramphenicol. A sequenceconfirmed correct plasmid was termed pDEST203. pDEST203 has a T7 promoter, a transcriptional unit encoding 6-histidine (6-His) fused to the HSV-1 polypeptide, attR recombination sites, and features suitable for in vitro transcription/translation. HSV-1 inserts from pENTR207 or pENTR221 were moved to pDEST203 using LR Clonase II to generate the pEXP203-ORF series. The left and right vector insert junctions of each pEXP203-ORF plasmid were sequenced to confirm identity and in-frame fusion with 6-His. Each pEXP203 construct encodes MSGSHHHHHHSSGIEGRGRLIKHMTMASRLESTSLYKKAGF at the N terminal, followed in-frame by the HSV-1 polypeptide. For expression, pEXP203 plasmids 
were prepared from a 3-ml ampicillin culture of transformed E. coli using a silica method (QIAGEN) and mass determined by spectrophotometry. Proteins were expressed using $50 \mu \mathrm{l}$ volumes of the Expressionway E. coli system (Invitrogen). To check expression, $1 \mu \mathrm{l}$ of reaction product was spotted onto nitrocellulose membranes (Whatman), air dried, blocked with $1 \%$ blocking reagent (Roche) diluted in TBS (50 mM Tris, $150 \mathrm{mM}$ $\mathrm{NaCl}, \mathrm{pH}$ 7.5), probed with anti-6-His mAb (Roche) diluted 1:500 in TBS$0.1 \%$ Tween 20 (TBS-T) (Roche), washed with TBS-T, incubated with HRPconjugated anti-mouse IgG (Promega) diluted 1:2,500 in TBS-T, washed with TBS-T, and developed with TMB substrate (Promega). Proteins failing to display a spot indicating anti-6-His binding were re-synthesized. For HSV-1 protein VP22 (gene UL49), expression was checked by triplicate, 3 -day $\left[{ }^{3} \mathrm{H}\right]$ thymidine proliferation assay using cornea-derived $\mathrm{CD}^{+}$clone 9447.28 specific for HSV-1 VP22 aa 199-211 (18) as responders $\left(2 \times 10^{4} /\right.$ well), autologous 3,300 rad- $\gamma$-irradiated PBMCs as APCs $\left(10^{5} /\right.$ well), and HSV-1 VP22 or controls expressed in the pEXP203 system.

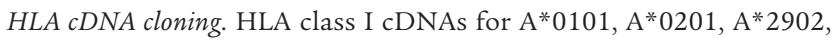
$B * 0702, B^{*} 0801, B^{*} 4402$, and $B^{*} 5801$ are documented $(52,56,71,84)$. Cloning of HLA-A*2402, $-A^{*} 2601$, and $-A^{*} 6801$ used $5^{\prime}$ primer CCGCCGCTAGCATGGCCGTCATGGCGCCCCGA and 3' primer CCGCCCTCGAGTCACACTTTACAAGCTGTG. Cloning of HLA-B*1516, -B*3503, -B*5101, and $-\mathrm{B} * 5801$ used 5 ' primer CCGCCGCTAGCATGCGGGTCACGGCGCCCCGAACCG and 3' primer CCGCCCTCGAGTCAAGCTGTGAGAGACACATCAG. Cloning of HLA-Cw0704 used 5' primer CCGCCTGCTAGCATGCGGGTCATGGCGCCCCGAG and 3' primer CCGCCCGTCTCGAGTCAGGCTTTACAAGTGATGAGAGAC. Cloning of HLA-Cw0102, -Cw0202, -Cw0401, -Cw0501, -Cw0701, -Cw0702, and -Cw1402 used 5' primer TATAAAGCTTTTCTCCCCAGACGCCGAGA and 3' primer ATATGCGGCCGCGTCTCAGGCTTTACAAGCGA (66). For new alleles, RNA was prepared from PBMCs or B-LCLs (79) (RNeasy kit, Invitrogen). cDNA synthesis used random hexamer primers (HLA-A, $-\mathrm{B}$, and -Cw0704) or oligo-dT (other HLA-C alleles) and Superscript II (Invitrogen). PCR used the above primer pairs (bold NheI and XhoI sites for HLA-A, -B, and -Cw0704; HindIII and NotI for other HLA-C; additional distal non-HLA sequences are shown in italics; HLA-specific sequences in regular type with ATG start codons are underlined for HLA-A, -B, and -Cw0704). PCR amplicons at the expected MW were digested with the restriction enzymes listed and cloned into pcDNA3.1(+) (Invitrogen) (HLA-A, -B, and -Cw0704) or pcDNA3.1/V5-His TOPO (Invitrogen) (other HLA-C). cDNA clones with $100 \%$ sequence matches (85) were prepared by anion exchange (QIAGEN). For validation of expression, Cos-7 cells were transfected with plasmid cDNA and FuGENE 6 (Boehringer MannheimRoche) for 48 hours, trypsinized, and surface stained for flow cytometry with anti-HLA mAb (A*0101: 0544HA; $A^{*} 0201$ : MA2.1, ref. 86; $A^{*} 2402$ : 0497HA; A*2601: 0544HA; A*2902: 0334HA; B*0801: 0059HA; B*1516: 0044HA; B*3503: 0789AHA; B*4402: 0786BHA; One Lambda, except MA2.1 as described in ref. 56). Isotype-appropriate fluorochrome-labeled polyclonal antibodies were used to detect primary antibody binding (81). Negative controls were Cos-7 cells stained with secondary antibody only, nontransfected Cos-7 cells with both antibodies, and HLA-mismatched B-LCLs; positive controls were HLA-matched B-LCLs. In some situations, HLA alleles were matched to participants based on low-resolution typing and knowledge of the most prevalent HLA allelic subtypes. Specifically, for participant 2 with HLA-B*07 and $-B * 08$, we used the most likely alleles, $B^{*} 0702$ and $B^{*} 0801$; for participant 5 with HLA-A*01 and $-B^{*} 08$ and $B * 51$, we used $A * 0101, B * 0801$, and $B * 5101$; and for participant 6 with $A * 24$, we used $A * 2402$. For one participant at each locus, only one genome scan was done for CD8 responses due to homozygosity or near homozygosity. Specifically, for participant 7, who had HLA-A*0220 and -A*0224 (each differing from $A * 0201$ at a single amino acid), we used $A * 0201$ only.
Participant 6 had both B*3503 and B*3502 (differing by 3 amino acids from $B * 3503$ ), of which only $B * 3503$ was studied, and was homozygous for HLA-C*04G1, for which Cw0401 was studied. Participant 4 had A*2901, but we used $A * 2902$ differing at one amino acid.

ORFeome CD8 screens. Cos-7 cells were plated in 96-well flat plates as described previously (56) and 24 hours later were simultaneously transfected with $50 \mathrm{ng}$ HLA cDNA and $150 \mathrm{ng} /$ well pDEST103-based HSV-1 construct. Each HSV-1 ORF or fragment was assayed in duplicate. Negative controls were pDEST103 mono-transfected. After 48 hours, bulk polyclonal $\mathrm{CD}^{+}$effector cells (above) were added at $5 \times 10^{4}$ to $10 \times 10^{4} /$ well in $200 \mu \mathrm{l}$ fresh TCM. After 16-24 hours, supernatants were collected and stored at $-20^{\circ} \mathrm{C}$. T cell activation was detected by supernatant ELISA for IFN- $\gamma(56)$.

ELISA data were designed to classify each HSV-1 ORF/HLA transfection combination as positive or negative for each responder $\mathrm{T}$ cell line. For an ORF to be considered positive, we required that both individual $\mathrm{OD}_{450}$ readings were 0.08 or greater for every screen, except for one with higher background, where the threshold was set at 0.1 . For ORFs screened as more than one fragment, or both a full-length and one or more internal fragments or separately annotated but in-frame genes, or exon by exon, the major ORF was considered the fundamental unit of analysis and was considered positive if one or more fragment(s) scored positive. Analyses grouped proteins by the kinetics of gene expression in the context of infected cells or by structural or functional biology from reviews (1) and primary literature, as well as by the presence or absence from virions (51).

ORFeome $\mathrm{CD} 4$ screens. Bulk-expanded HSV-1-reactive $\mathrm{CD} 4^{+} \mathrm{T}$ cell lines were tested for proliferative responses to individual HSV-1 proteins as described for vaccinia $(87,88)$. Briefly, $5 \times 10^{4}$ to $10 \times 10^{4}$ autologous $\gamma$-irradiated (3,300 rad) PBMCs, $3 \times 10^{4}$ bulk responder cells, and recombinant HSV-1 proteins (above) diluted 1:5,000 were plated in duplicate in $200 \mu \mathrm{l} \mathrm{TCM} \mathrm{in}$ 96-well U-bottom plates. Negative controls included similar dilutions of the in vitro transcription/translation products of plasmids encoding Francisella tularensis proteins, empty pDEST203, or no DNA. F. tularensis ShuS4 molecular clones of genes 1208, 1127, 1305, 7056, 1306, 1314, 1961, 5396, 1852, $1254,1729,1695,1544,1835$, and 1963 in vector pXT7 (89) were maintained in E. coli under kanamycin selection. Protein was synthesized as described for HSV-1. UV-treated HSV-1 and mock virus were positive and negative controls. $\left[{ }^{3} \mathrm{H}\right]$ thymidine incorporation was measured after 3 days (47). The criteria for designating an HSV-1 ORF or fragment as positive used the negative controls $(n=30)$ and was set as the mean plus 3.09 times the SD of the negative controls $(n=30)$ (47) for a 1-tailed false discovery rate of $0.1 \%$.

ICC. The reactivity of $\mathrm{T}$ cell responder cultures was tested by ICC as described previously (87). The format for checking CD8 reactivity with whole virus involved infected autologous B-LCLs with mock virus, HSV-1, HSV-2, or vaccinia for 18 hours at MOI 5, washing, and coculturing $2 \times 10^{5}$ B-LCLs with $2 \times 10^{5}$ responder T cells in $1 \mathrm{ml} \mathrm{TCM}$. For CD4 reactivity, $2 \times 10^{5}$ autologous, CFSE-labeled PBMCs were cocultured with $2 \times 10^{5}$ responder T cells and UV-treated HSV-1, HSV-2, vaccinia, or mock virus at 1:100 dilution in $1 \mathrm{ml} \mathrm{TCM}$. For peptides, responder $\mathrm{T}$ cells were cocultured with equal numbers $\left(\sim 10^{5}\right)$ of CFSE pre-labeled autologous B-LCLs and $1 \mu \mathrm{g} / \mathrm{ml}$ peptide or an equivalent volume of DMSO as negative control. Either staphylococcal enterotoxin B (SEB, $1 \mu \mathrm{g} / \mathrm{ml}, \mathrm{BD})$ or PMA and ionomycin (88) were used as positive control. Anti-CD28 and anti-CD49d were added at assay setup, and brefeldin A was used to reduce cytokine secretion. Cells were surface stained for CD8 or CD4 as appropriate, permeabilized, and stained intracellularly for IFN- $\gamma$, and in some cases also for TNF- $\alpha$ and IL-2 (80). After appropriate washes and fixation, CFSE-negative cells in the lymphocyte forward and side scatter gates were analyzed by flow cytometry for binding of fluorochrome-labeled antibodies. For peptides, responses were considered positive if a discrete group of IFN- $\gamma$-expressing cells was observed and the percentage of IFN $-\gamma^{+}$cells was greater than $2 \times$ 
DMSO background. Low-positive peptide responses were repeated at least once including new negative controls, and only repeatedly reactive peptide responses were considered positive and are reported herein.

Cytolysis assays. The cytolytic activity of sorted, bulk, polyclonally expanded $\mathrm{T}$ cell responder cultures was tested in ${ }^{51} \mathrm{Cr}$ release assays (90). Briefly, target cells were created by infection of autologous or HLA class I-mismatched allogeneic B-LCLs with HSV-1 or vaccinia at an MOI of 5 for 18 hours $(90)$ while labeling with ${ }^{51} \mathrm{Cr}$. Washed target cells $\left(2 \times 10^{3} /\right.$ well $)$ were cocultured in triplicate in 96-well U-bottom plates with a 40 -fold excess of responder cells for 4 hours at $37^{\circ} \mathrm{C}, 5 \% \mathrm{CO}_{2}$. Media or 5\% IGEPAL (SigmaAldrich) were used for spontaneous and total ${ }^{51} \mathrm{Cr}$ release, respectively. Thirty microliters of supernatant was counted using Lumaplates and a TopCount (Packard). Data are reported as percent specific release (90); spontaneous release (90) was typically less than $20 \%$.

ELISPOT. For direct testing of PBMCs ex vivo, duplicate IFN- $\gamma$ ELISPOT was done as described previously, except that unmanipulated PBMCs were used (53). Thawed PBMCs were tested at $7.5 \times 10^{5} /$ well. Stimuli were HSV-1 peptides $(1 \mu \mathrm{g} / \mathrm{ml}, n=41), 0.1 \%$ DMSO negative control, and UV-killed HSV-1 at 1:100 dilution as positive control. Five peptides were omitted: HSV-1 UL53 201-209 (HLA-A*0101 restricted), UL26 326-334 and UL27 641-649 (HLA-A*2909 restricted), and US7 22-30 and ICP0 698-706 (HLA-B*0702 restricted). Potential positives were manually reviewed using high-density images. Peptides with more than $10 \mathrm{SFU}$ per $10^{6} \mathrm{PBMCs}$ and greater than $2 \times$ DMSO background were considered positive.

HSV-1 peptides. The predicted amino acid sequences for HSV-1 ORFs or fragments that were reactive in CD8 ORFeome analyses were submitted with the restricting HLA class I alleles to binding prediction algorithms (91). Top-ranking 9-mers or 10-mers were synthesized with native termini, usually 3-10 per ORF per HLA allele (Sigma-Aldrich). We also purchased peptides gD1 (gene US6) 77-85 (SLPITVYYA), 94-102 (VLLNAPSEA), and 302-310 (ALLEDPVGT), reported to bind HLA-A*0201 tightly and to be $\mathrm{A}^{*}$ 0201-restrcited epitopes in gD1 (16). Peptide HSV-1 UL25 367-375 was made as described previously (54). Throughout, amino acid 1 refers to the genomic ATG encoding methionine, rather than alternative numbering schemes (16). The manufacturer characterized peptide MW by mass spectroscopy. Peptides were diluted to $10 \mathrm{mg} / \mathrm{ml}$ in DMSO, stored at $-20^{\circ} \mathrm{C}$, and further diluted in TCM.

Statistics. For CD4 ORFeome screens, HSV-1 ORFs with mean cpm values above the mean plus 3.09 times the SD for negative controls were considered positive for a 1 -tail false discovery rate of $0.1 \%$ (87). This $q$ statistic for false discovery rates is generally considered to be analogous to the $P$ value; in this case $0.1 \%$ corresponds to $P$ of 0.001 . For CD8 ORFeome screens, the mean background raw IFN- $\gamma$ ELISA OD $_{450}$ values were typically 0.05 and were normally distributed. ORFs for which each duplicate well yielded an IFN- $\gamma$ ELISA OD $_{450}$ value greater than $2 \times$ the mean background value raw $\mathrm{OD}_{450}$ (typically 0.08 ) were considered positive.

Study approval. Healthy adults with HSV-1 infection or a history of vaccinia vaccination were studied under a protocol approved by the University of Washington IRB, Seattle, Washington, USA. Participants provided informed written consent.

\section{Acknowledgments}

We gratefully acknowledge the participation of research participants with HSV infection at the University of Washington Virology Research Clinic. The clinical and regulatory staff at the Clinic provided invaluable assistance in obtaining the clinical specimens. The Virology Laboratory at Children's Medical Center, Seattle, Washington, performed HSV type-specific serology. HIV-1 serology was done at the University of Washington. We thank M. Juliana McElrath and the HIV Vaccine Trials Network and the AIDS Clinical Trial Group for cell sorter help. We thank Joseph Blattman for help with fluorescence microscopy and flow cytometry. We thank Phil Felgner and D. Huw Davies for F. tularensis molecular clones. We thank Amanda Paulovich for use of equipment. We thank Stanley R. Riddell for assisting with the HLA C cDNA clones. Funding was provided by NIH grants AI30731, AI094019, AI081060, AI042528, BayGene (Bayerisches Staatsministerium für Wissenschaft, Forschung, und Kunst; J. Haas), the Deutsche Forschungsgemeinschaft (DFG; SFB 576, BA 1165/5-1), and the Medical Research Council (MRC; G0501453). We thank the James B. Pendleton Charitable Trust for purchase of a BD FACSAria flow cytometer cell sorter. Support was also provided by the Bill and Melinda Gates Foundation via the Poxvirus T Cell Vaccine Discovery Consortium (PTVDC) within the Collaborative AIDS Vaccine Discovery (CAVD) program.

Received for publication August 17, 2011, and accepted in revised form November 9, 2011.

Address correspondence to: David M. Koelle, 1616 Eastlake Avenue East, Suite 500, Seattle, Washington 98102, USA. Phone: 206. 667.6491; Fax: 206.667.7711; E-mail: viralimm@u.washington.edu.
1. Roizman B, Knipe DM, Whitley RJ. Herpes simplex viruses. In: Knipe DM, Howley PM, eds. Fields Virology. Philadelphia, Pennsylvania, USA: Lippincott, Williams, and Wilkins; 2007:2501-2602.

2. Stanberry LR, et al. Prophylactic vaccination against genital herpes with adjuvanted recombinant glycoprotein $D$ vaccine: two randomized contolled trials. N Engl J Med. 2002;347(21):1652-1661.

3. Verjans GMGM, et al. Selective retention of herpes simplex virus specific $T$ cells in latently infected human trigeminal ganglia. Proc Natl Acad Sci U S A. 2007;104(9):3496-3501.

4. Lichen J, et al. Tegument- and glycoprotein-reactive HSV-1-specific CD4 and CD8 T cells localize to human trigeminal ganglia [abstract]. Jimmunol.2009; 182:128.24.

5. Prabhakaran K, et al. Sensory neurons regulate the effector functions of CD8+ T cells in controlling HSV-1 latency ex vivo. Immunity. 2005;23(5):515-525.

6. Zhu J, et al. Virus-specific CD8+ T cells accumulate near sensory nerve endings in genital skin during subclinical HSV-2 reactivation. J Exp Med. 2007; 204(3):595-603.
7. Zhu J, et al. Persistence of HIV-1 receptor-positive cells after HSV-2 reactivation is a potential mechanism for increased HIV-1 acquisition. Nat Med. 2009; 15(8):886-892.

8. Gebhardt T, Wakim LM, Eidsmo L, Reading PC, Heath WR, Carbone FR. Memory T cells in nocnlymphoid tissue that provide enhanced local immunity during infection with herpes simplex virus. Nat Immunol. 2009;10(5):524-530.

9. Sawtell NM. The probability of in vivo reactivation of herpes simplex virus type 1 increases with the number of latently infected neurons in the ganglia. J Virol. 1998;72(8):6888-6892.

10. Sawtell NM, Thompson RL, Stanberry LR, Bernstein DI. Early intervention with high-dose acyclovir treatment during primary herpes simplex virus infection reduces latency and subsequent reactivation in the nervous system in vivo. J Infect Dis. 2001;184(8):964-971.

11. Orr MT, Orgun NN, Wilson CB, Way SS. Cutting Edge: Recombinant Listeria monocytogenes expressing a single immune-dominant peptide confers protective immunity to herpes simplex virus-1 infection. J Immunol. 2007;178(8):4731-4735

12. Iijima N, et al. Dendritic cells and B cells maximize mucosal Th1 memory response to herpes simplex virus. J Exp Med. 2008;205(13):3041-3052.

13. Schacker T, Zeh J, Hu H-L, Hill E, Corey L. Frequency of symptomatic and asymptomatic herpes simplex virus type 2 reactivations among human immunodeficiency virus-infected men. J Infect Dis. 1998;178(6):1616-1622.

14. McGeoch DJ, Dolan A, Donald S, Brauer DH. Complete DNA sequence of the short repeat region in the genome of herpes simplex virus type 1. Nucleic Acids Res. 1986;14(4):1727-1745.

15. McGeoch DJ, et al. The complete DNA sequence of the long unique region of herpes simplex virus type 1 . J Gen Virol. 1988;69(pt 7):1531-1574.

16. Chentoufi AA, et al. HLA-A*0201-restricted CD8+ cytotoxic $T$ lymphocyte epitopes identified from herpes simplex virus glycoprotein D. J Immunol. 2008;180(1):426-437.

17. Chentoufi AA, et al. A novel HLA (HLA-A*0201) transgenic rabbit model for preclinical evaluation of human $\mathrm{CD} 8+\mathrm{T}$ cell epitope-based vaccines against 
ocular herpes. J Immunol. 2010;184(5):2561-2571.

18. Koelle DM, et al. Tegument-specific, virus-reactive CD4 $\mathrm{T}$ cells localize to the cornea in herpes simplex virus interstitial keratitis in humans. J Virol. 2000;74(23):10930-10938.

19. Verjans GMGM, et al. Identification and characterization of herpes simplex virus-specific CD4+ $\mathrm{T}$ cells in corneas of herpetic stromal keratitis patients. J Infect Dis. 1998;177(2):484-488.

20. Verjans GMGM, Remeijer L, Mooy CM, Osterhaus ADME. Herpes simplex virus specific T-cells infiltrate the cornea of patients with herpes stromal keratitis: no evidence for intra-corneal autoreactive T-cells in human HSK. Invest Ophthalmol Vis Sci. 2000;41(9):2607-2612.

21. Remeijer L, Osterhaus A, Verjans G. Human herpes simplex virus keratitis: the pathogenesis revisited. Ocul Immunol Inflamm. 2004;12(4):255-285.

22. Verjans GM, et al. Intraocular T cells of patients with herpes simplex (HSV)-induced acute retinal necrosis recognize HSV tegument proteins VP11/12 and VP13/14. J Infect Dis. 2000;182(3):923-927.

23 . Verjans $\mathrm{GM}$, et al. T cells specific for the triggering virus infiltrate the eye in patients with herpes simplex virus-mediated acute retinal necrosis. J Infect Dis. 1998;178(1):27-34.

24. Yasukawa M, Zarling JM. Human cytotoxic T cell clones directed against herpes simplex virus-infected cells. III. Analysis of viral glycoproteins recognized by CTL clones by using recombinant herpes simplex viruses. JImmunol. 1985;134(4):2679-2687.

25. Hoshino Y, et al. Comparative efficacy and immunogenicity of replication-defective, recombinant glycoprotein, and DNA vaccines for herpes simplex virus 2 infections in mice and guinea pigs. J Virol. 2005;79(1):410-418.

26. de Bruyn G, et al. A randomized controlled trial of a replication defective ( $\mathrm{gH}$ deletion) herpes simplex virus vaccine for the treatment of recurrent genital herpes among immunocompetent subjects. Vaccine. 2006;24(7):914-920.

27. Aurelian L, Kokuba H, Smith CC. Vaccine potential of a herpes simplex virus type 2 mutant deleted in the PK domain of the large subunit of ribonucleotide reductase (ICP10). Vaccine. 1999; 17(15-16):1951-1963.

28. York IA, Roop C, Andrews DW, Riddell SR, Graham FL, Johnson DC. A cytosolic herpes simplex protein inhibits antigen presentation to CD8+ T lymphocytes. Cell. 1994;77(4):525-535.

29. Hill A, et al. Herpes simplex virus turns off the TAP to evade host immunity. Nature. 1995; 375(6530):411-415.

30. Tigges MA, Leng S, Johnson DC, Burke RL. Human herpes simplex (HSV)-specific CD8+ CTL clones recognize HSV-2-infected fibroblasts after treatment with IFN-gamma or when virion host shutoff functions are disabled. J Immunol. 1996;156(10):3901-3910.

31. Posavad CM, Newton JJ, Rosenthal KL. Inhibition of human CTL-mediated lysis by fibroblasts infected with herpes simplex virus. I Immunol. 1993;151(9):4865-4873.

32. Sloan DD, et al. Inhibition of TCR signaling by herpes simplex virus. J Immunol. 2006;176(3):1825-1833.

33. Jirmo AC, Nagel CH, Bohnen C, Sodeik B, Behrens GM. Contribution of direct and cross-presentation to CTL immunity against herpes simplex virus 1 . J Immunol. 2009;182(1):283-292.

34. Smith CM, et al. Cutting Edge: Conventional CD8al$\mathrm{pha}(+)$ dendritic cells are preferentially involved in CTL priming after footpad infection with herpes simplex virus-1. J Immunol. 2003;170(9):4437-4440.

35. Allan RS, et al. Epidermal viral immunity induced by CD8alpha+ dendritic cells but not by Langerhans cells. Science. 2003;301(5641):1925-1928.

36. Allan RS, et al. Migratory dendritic cells transfer antigen to a lymph node-resident dendritic cell population for efficient CTL priming. Immunity.
2006;25(1):153-162.

37. Wakim LM, Waithman J, van Rooijen N, Heath WR, Carbone FR. Dendritic cell-induced memory $\mathrm{T}$ cell activation in nonlymphoid tissues. Science. 2008;319(5860):198-202.

38. Bedoui S, et al. Cross-presentation of viral and self antigens by skin-derived CD103+ dendritic cells. Nat Immunol. 2009;10(5):488-495.

39. Bosnjak L, Miranda-Saksena M, Koelle DM, Boadle RA, Jones CA, Cunningham AL. Herpes simplex virus infection of human dendritic cells induces apoptosis and allows cross-presentation via uninfected dendritic cells. J Immunol. 2005;174(4):2220-2227.

40. Wolfl M, Kuball J, Eyrich M, Schlegel PG, Greenberg PD. Use of CD137 to study the full repertoire of CD8+ T cells without the need to know epitope specificities. Cytometry A. 2008;73(11):1043-1049.

41. Wehler TC, et al. Rapid identification and sorting of viable virus-reactive CD4(+) and CD8(+) T cells based on antigen-triggered CD137 expression. J Immunol Methods. 2008;339(1):23-37.

42. Watanabe K, et al. CD137-guided isolation and expansion of antigen-specific CD8 cells for potential use in adoptive immunotherapy. Int J Hematol. 2008;88(3):311-320.

43. Corey L, et al. Two double-blind, placebo-controlled trials of a vaccine containing recombinant $\mathrm{gD} 2$ and gB2 antigens in MF59 adjuvant for the prevention of genital HSV-2 acquisition. JAMA. 1999; 282(4):331-340.

44. Straus SE, et al. Placebo-controlled trial of vaccination with recombinant glycoprotein D of herpes simplex virus type 2 for immunotherapy of genital herpes. Lancet. 1994;343(8911):1460-1463.

45. Straus SE, et al. Immunotherapy of recurrent genital herpes with recombinant herpes simplex virus type 2 glycoproteins B and D: results of a placebo-controlled vaccine trial. J Infect Dis. 1997; 176(5):1129-1134.

46. Koelle DM, Schomogyi M, McClurkan C, Reymond SN, Chen HB. CD4 T-cell responses to herpes simplex virus type 2 major capsid protein VP5: comparison with responses to tegument and envelope glycoproteins. J Virol. 2000;74(23):11422-11425.

47. Jing L, et al. An extremely diverse CD4 response to vaccinia virus in humans is revealed by proteomewide T cell profiling. JVirol. 2008;82(14):7120-7134.

48. Sylwester AW, et al. Broadly targeted human cytomegalovirus-specific CD4+ and CD8+ T cells dominate the memory compartments of exposed subjects. J Exp Med. 2005;202(5):673-685

49. Saulquin $X$, et al. A global appraisal of immunodominant CD8 $\mathrm{T}$ cell responses to Epstein-Barr virus and cytomegalovirs by bulk screening. Eur J Immunol. 2000;30(9):2531-2539.

50. Hislop AD, Taylor GS, Sauce D, Rickinson AB. Cellular responses to viral infection in humans: lessons from Epstein-Barr virus. Annu Rev Immunol. 2007;25:587-617

51. Loret S, Guay G, Lippe R. Comprehensive characterization of extracellular herpes simplex virus type 1 virions. J Virol. 2008;82(17):8605-8618.

52 . Koelle DM, et al. Immunodominance among herpes simplex virus-specific CD8 T cells expressing a tissue-specific homing receptor. Proc Natl Acad Sci US A. 2003;100(22):12899-12904.

53. Koelle DM, et al. Phase I dose-escalation study of a monovalent heat shock protein 70-herpes simplex virus type 2 (HSV-2) peptide-based vaccine designed to prime or boost CD8 T-cell responses in HSV-naive and HSV-2-infected subjects. Clin Vaccine Immunol. 2008;15(5):773-782.

54. Laing KJ, et al. Diversity in CD8(+) T cell function and epitope breadth among persons with genital herpes. J Clin Immunol. 2010;30(5):703-722.

55. Koelle DM, Corey L. Herpes simplex: insights on pathogenesis and possible vaccines. Annu Rev Med. 2008;59:381-395.
56. Koelle DM, Chen HB, Gavin MA, Wald A, Kwok WW, Corey L. CD8 CTL from genital herpes simplex lesions: recognition of viral tegument and immediate early proteins and lysis of infected cutaneous cells. JImmunol. 2001;166(6):4049-4058.

57. Dong L, Li P, Oenema T, McClurkan CL, Koelle DM. Public TCR use by herpes simplex virus2-specific human CD8 CTLs. J Immunol. 2010; 184(6):3063-3071.

58. Cunningham AL, Turner RR, Miller AC, Para MF, Merigan TC. Evolution of recurrent herpes simplex lesions: an immunohistologic study. J Clin Invest. 1985;75(1):226-233.

59. Dufour F, Sasseville AM, Chabaud S, Massie B, Siegel RM, Langelier Y. The ribonucleotide reductase R1 subunits of herpes simplex virus types 1 and 2 protect cells against TNFalpha- and FasL-induced apoptosis by interacting with caspase-8. Apoptosis. 2011;16(3):256-271

60. St Leger AJ, Peters B, Sidney J, Sette A, Hendricks RL. Defining the herpes simplex virus-specific CD8+ T cell repertoire in C57BL/6 mice. J Immunol. 2011;186(7):3927-3933.

61. Tomazin R, et al. Herpes simplex virus type 2 ICP47 inhibits human TAP but not mouse TAP. J Virol. 1998;72(3):2560-2563.

62. Tigges MA, Koelle DM, Hartog K, Sekulovich RE, Corey L, Burke RL. Human CD8+ herpes simplex virus-specific cytotoxic T lymphocyte clones recognize diverse virion protein antigens. J Virol. 1992;66(3):1622-1634.

63. Puttur FK, et al. Herpes simplex virus infects skin gamma delta $T$ cells before Langerhans cells and impedes migration of infected Langerhans cells by inducing apoptosis and blocking E-cadherin downregulation. J Immunol. 2010;185(1):477-487.

64. Jin H, Yan Z, Ma Y, Cao Y, He B. A herpesvirus virulence factor inhibits dendritic cell maturation through protein phosphatase 1 and Ikappa B kinase. J Virol. 2011;85(7):3397-3407.

65. Salio M, Cella M, Suter M, Lanzavecchia A. Inhibition of dendritic cell maturation by herpes simplex virus. Eur J Immunol. 1999;29(10):3245-3253.

66. Akatsuka Y, et al. Efficient cloning and expression of HLA class I cDNA in human B-lymphoblastoid cell lines. Tissue Antigens. 2002;59(6):502-511.

67. Koelle DM, et al. Expression of cutaneous lymphocyte-associated antigen by CD8(+) T cells specific for a skin-tropic virus. JClin Invest. 2002;110(4):537-548.

68. Posavad CM, Wald A, Hosken N, Huang M-L, Koelle DM, Corey L. T cell immunity to herpes simplex virus in seronegative persons: silent infection or acquired immunity. J Immunol. 2003;170(8):4380-4388.

69. Zaunders JJ, et al. High levels of human antigenspecific CD4+ $\mathrm{T}$ cells in peripheral blood revealed by stimulated coexpression of CD25 and CD134 (OX40). J Immunol. 2009;183(4):2827-2836.

70. Ashley RL, Militoni J, Lee F, Nahmias A, Corey L. Comparison of Western blot (immunoblot) and glycoprotein G-specific immunodot enzyme assay for detecting antibodies to herpes simplex virus types 1 and 2 in human sera. J Clin Microbiol. 1988; 26(4):662-667.

71. Jing L, Chong TM, McClurkan CL, Huang J, Story BT, Koelle DM. Diversity in the acute CD8 T cell response to vaccinia virus in humans. J Immunol. 2005;175(11):7550-7559.

72. Koelle DM, et al. Antigenic specificity of human CD4+ T cell clones recovered from recurrent genital HSV-2 lesions. J Virol. 1994;68(5):2803-2810.

73. Marsh SG, et al. Nomenclature for factors of the HLA system, 2010. Tissue Antigens. 2010;75(4):291-455.

74. Spruance SL, Chow FS. Pathogenesis of herpes simplex virus in cultures of epidermal cells from subjects with frequent recurrences. J Infect Dis. 1980; 142(5):671-675

75. Kit S, Kit M, Qavi H, Trkula D, Otsuka H. Nucleotide sequence of the herpes simplex virus type 2 (HSV-2) 
thymidine kinase gene and predicted amino acid sequence of thymidine kinase polypeptide and its comparison with the HSV-1 thymidine kinase gene. Biochim Biophys Acta. 1983;741(2):158-170.

76. Jing L, Chong TM, McClurkan CL, Huang J, Story BT, Koelle DM. Diversity in the acute CD8 T cell response to vaccinia virus in humans [published correction appears in J. Immunol. 2007;179(4):2659]. J Immunol. 2005;175(11):7550-7559.

77. Jing $\mathrm{L}$, et al. Dominance and diversity in the primary human CD4 T cell response to replication-competent vaccinia virus. J Immunol. 2007;178(10):6374-6386.

78. Yasukawa M, Zarling JM. Autologous herpes simplex virus-infected cells are lysed by human natural killer cells. J Immunol. 1983;131(4):2011-2016.

79. Koelle DM, Chen H, Gavin MA, Wald A, Kwok WW, Corey L. CD8 CTL from genital herpes simplex lesions: recognition of viral tegument and immediate early proteins and lysis of infected cutaneous cells. J Immunol. 2001;166(6):4049-4058.

80. Quakkelaar ED, et al. Enhanced expression of HIV antigens and improved cross-presentation by replication competent recombinant vaccinia virus vec- tor. PLoS ONE. 2011;6(2):e16819.

81. Koelle DM. Expression cloning for the discovery of viral antigens and epitopes recognized by T-cells. Methods. 2003;29(3):213-226.

82. Koelle DM, Frank JM, Johnson ML, Kwok WW. Recognition of herpes simplex virus type 2 tegument proteins by CD4 T cells infiltrating human genital herpes lesions. J Virol. 1998;72(9):7476-7483.

83. Kask AS, et al. DNA vaccine delivery by denselypacked and short microprojection arrays to skin protects against vaginal HSV-2 challenge. Vaccine. 2010;28(47):7483-7491

84. Koelle DM, Chen HB, McClurkan CM, Petersdorf EW. Herpes simplex virus type 2-specific CD8 cytotoxic $\mathrm{T}$ lymphocyte cross-reactivity against prevalent HLA class I alleles. Blood. 2002;99(10):3844-3847.

85. Robinson J, Malik A, Parham P, Bodmer JG, Marsh SG. IMGT/HLA database-a sequence database for the human histocompatibility complex. Tissue Antigens. 2000;55(3):280-287.

86. McMichael AJ, Parham P, Rust N, Brodsky F. A monoclonal antibody that recognizes an antigenic determinant shared by HLA A2 and B17. Hum
Immunol. 1980;1(2):121-129.

87. Jing L, et al. An extremely diverse CD4 response to vaccinia virus in humans is revealed by proteomewide T-cell profiling. J Virol. 2008;82(14):7120-7134.

88. Jing L, et al. ORFeome approach to the clonal, HLA allele-specific CD4 T-cell response to a complex pathogen in humans. J Immunol Methods. 2009; 347(1-2):36-45.

89. Eyles JE, et al. Immunodominant Francisella tularensis antigens identified using proteome microarray. Proteomics. 2007;7(13):2172-2183.

90. Koelle DM, Posavad CM, Barnum GR, Johnson ML, Frank JM, Corey L. Clearance of HSV-2 from recurrent genital lesions correlates with infiltration of HSV-specific cytotoxic T lymphocytes. J Clin Invest. 1998;101(7):1500-1508.

91. Vita R, et al. The immune epitope database 2.0. Nucleic Acids Res. 2010;38(Database issue):D854-D862.

92. Marsh SGE, Parham P, Barber LD. The HLA FactsBook. San Diego, California, USA: Academic Press; 2000.

93. Koelle DM, et al. Expression of cutaneous lymphocyte-associated antigen by CD8+ T-cells specific for a skin-tropic virus. J Clin Invest. 2002;110(4):537-548. 